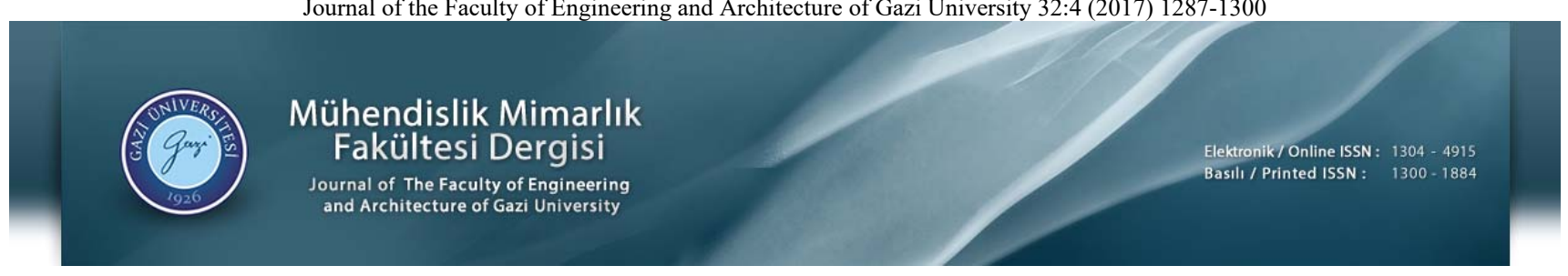

\title{
Gömülü bir platform üzerinde gerçek zamanlı şeritten ayrılma uyarı sistemi
}

\author{
Ayhan Küçükmanisa (D), Oğuzhan Urhan*(D) \\ Kocaeli Üniversitesi, Mühendislik Fakültesi, Elektronik ve Haberleşme Mühendisliği Bölümü, İzmit-Kocaeli, 41380, Türkiye
}

\section{Ö N E C I K A N L A R}

- Yüksek şerit tespit başarımı

- Düşük işlem yüküne sahip şerit tespit algoritması

- Gömülü bir platformda gerçekleme

Makale Bilgileri

Geliş: 18.01.2017

Kabul: 20.02.2017

DOI:

10.17341/gazimmfd.369719

Anahtar Kelimeler:

Seritten ayrılma uyarı

sistemi,

şerit tespiti,

gömülü sistemler

\section{ÖZET}

$\mathrm{Bu}$ çalışmada gömülü bir platform üzerinde gerçek zamanlı çalışan şeritten ayrılma uyarı sistemi önerilmiştir. Önerilen sistemde sürücülerin sürüș sırasında dikkatsizlik, uykuya dalmaları vb. nedenler ile aracın kontrolünü kaybederek istemsiz bir şekilde şerit değiş̧irdikleri görüntü işleme yaklaşımları ile tespit edilerek sürücüye uyarı verilmektedir. Bu çalışmada önerilen sistemde öncelikle uygulanan bir filtre ile şerit işareti öne çıkarılarak, şerit işareti tespit işıleminin olası bozucu etkilere karşı gürbüz bir şekilde çalışması sağlanmaktadır. Sonraki adımda filtrelenmiş giriş görüntüsü ile 1-D Gaussian fonksiyonunun korelasyon işlemi sonucu şerit çizgisi aday noktaları belirlenmektedir. Belirlenen bu aday noktalarından olası bozucular RANSAC (RANdom SAmple Consensus) yöntemi kullanılarak elenmektedir ve șerit çizgileri elde edilmektedir. Ayrıca tespit edilen şerit çizgilerinin konumlarının zamansal ilişkisi Kalman filtresi ile incelenmektedir. Elde edilen şerit çizgisi konumları ve önceden belirlenen araç konumu yorumlanarak aracın şeritten ayrılma durumu tespit edilmektedir. Geliştirilen sistem $752 \times 480$ uzamsal boyutuna sahip giriş görüntüleri için $1 \mathrm{GHz}$ frekansında ARM A8 işlemci üzerinde 16 fps'de çalışmaktadır.

\section{Real-time lane departure warning system on an embedded platform}

\section{H I G H L I G H T S}

- High performance lane detection

- Low complexity lane detection algorithm

- Embedded implementation

Article Info

Received: 18.01 .2017

Accepted: 20.02.2017

DOI:

10.17341/gazimmfd.369719

Keywords:

Lane departure warning system,

lane detection, embedded systems

\section{ABSTRACT}

In this work, a real-time lane departure warning system with its embedded implementation is proposed. In the proposed method, unintended lane departures that are originating from drivers falling asleep, carelessness etc. are detected using image processing based approaches. In this study, initially lane markings are extracted by making use of a filter to provide lane marking detection process robust against to possible outliers. At the next stage, correlation of the input image segments with a 1-D Gaussian function is computed to determine candidate lane markings. Possible outliers at this stage are eliminated using RANSAC (RANdom SAmple Consensus) approach and lane markings are obtained. Additionally, temporal relationship of the detected lane markings is examined via Kalman filter. Vehicle lane departure decision is given by interpreting the obtained lane markings and predetermined vehicle positions. The developed system is able to process $16 \mathrm{fps}$ on a $1 \mathrm{GHz}$ ARM Cortex A8 processor for input images of size $752 \times 480$.

\footnotetext{
*Sorumlu Yazar/Corresponding Author: urhano@kocaeli.edu.tr / Tel: +90 2623033352
} 


\section{GİRİŞ (INTRODUCTION)}

Günümüzde artan araç sayısı ile birlikte Akıllı Ulaşım Sistemlerine (Intelligent Transportation Systems - ITS) olan ilgi de artmaktadır. Akıllı ulaşım sistemlerinin temel amacı ulaşım teknolojilerinin gelişmesi ve trafik güvenliğini arttırmaktır. Sürücülere sürüşleri sırasında destek olarak kusurları ile ilgili destek veren akıllı ulaşım sistemleri İleri Sürücü Destek Sistemleri (Advanced Driver Assistance Systems - ADAS) olarak adlandırılmaktadır. Bir ileri sürücü destek sistemi olan Şeritten Ayrılma Uyarı Sistemleri (Lane Departure Warning Systems - LDWS) dikkatsizlik, sürücülerin uykuya dalmaları vb. nedenlerle sürücülerin araçlarının kontrolünü kaybederek istemsiz bir şekilde şerit değiştirmeleri sonucu oluşacak kazaların önüne geçmeyi amaçlamaktadır. Avrupa Komisyonu Enerji ve Ulaşım Genel Müdürlüğü tarafindan yayınlanan bir raporda şeritten ayrılma uyarı sistemlerinin kullanımı üzerine incelemeler yapılmıştır. $\mathrm{Bu}$ rapora göre şeritten ayrılma uyarı sistemlerinin kullanımı ile 2020 yılına kadar Avrupa genelinde 5 binden fazla ölümün ve 30 binden fazla ciddi yaralanmanın önüne geçilebileceği öngörülmektedir [1].

Şerit ihlalleri, şerit çizgilerinin konumlarının yorumlanmasıyla tespit edilebilmektedir. Dolayısıyla şerit çizgilerinin başarılı bir şekilde tespit edilmesi bu işlemin ilk aşaması olarak gerekmektedir. $\mathrm{Bu}$ çalışmada şerit işaretlerinin tespit edilmesi için bir hastalığın teşhis ve tedavisi [2], bir oyun içerisinde veri gizleme [3] ve tıbbi görüntüleme yöntemlerine destek [4] gibi farkl1 uygulama alanları bulunan görüntü işleme temelli bir yöntem kullanılmıştır. Literatürde tek veya çoklu kamera (stereo) kullanan birçok farklı görüntü işleme tabanlı şerit tespit yöntemi mevcuttur. $\mathrm{Bu}$ yöntemler genel olarak incelendiğinde ön işlem (preprocessing), özellik çıkartımı (feature extraction) ve son işlem (post processing) olmak üzere üç temel aşamadan oluşmaktadır. Ön işlem adımı, şerit tespit işleminin olası bozucu etkilere karşı (yağmur, sis, gölge, aşırı 1şıklılık vb.) gürbüz bir şekilde çalışması için giriş görüntüsünün iyileştirilmesini veya sonraki aşamaların bu bozuculardan etkilenmemesini amaçlamaktadır. Şerit tespit adımında şerit çizgilerinin tespit edilmesini sağlayacak aday özellik noktaları belirlenmektedir. Son işlem adımında ise aday şerit çizgisi özellik noktalarından bozucu olanlar elenerek şerit çizgileri tespit edilmektedir. Ayrıca bu adımda bazı yöntemlerde ek olarak şerit çizgilerinin konumlarının zamansal ilişkisi de incelenerek yanlış tespitlerin önüne geçilmesi amaçlanmaktadır. Gaikwad ve Lokhande [5] şerit çizgilerinin tespit işlemini kolaylaştırmak amacıyla PLSF (Piecewise Linear Stretching Function) tabanlı bir ön işlem önermiştir. $\mathrm{Bu}$ yaklaşımda PLSF yöntemiyle iyileştirilmiş görüntüler üzerinde Canny kenar tespiti ve sonrasında Hough dönüşümü [6] uygulanmaktadır. $\mathrm{Bu}$ işlem sonrası elde edilen çizgiler yorumlanarak son şerit çizgisi konumları tespit edilmektedir. Son olarak Öklid (Euclidean) uzaklığ tabanlı bir yaklaşım ile şeritten ayrılma uyarı durumu tespit edilmektedir. Kesikli şerit çizgilerinin tespiti devamlı şerit çizgilerine kıyasla daha zordur. Borkar vd. [7] tarafından yapılan çalışmada belirli aralıklarla (örneğin 3 çerçevede bir) ardışık çerçevelerin ortalaması alınarak elde edilen ortalama imge görüntüsünde kesikli yol çizgilerinin devamlı yol çizgileri haline getirilmesi amaçlanmıştır. Bu ortalama imge üzerinde şerit çizgilerinin paralellik özelliğinden yararlanmak amaciyla IPM (Inverse Perspective Mapping) [8] dönüşümü kullanılarak kamera düzlemi yerine dünya düzleminde çalışılmaktadır. Yöntemde özellik çıkartımı aşamasında aday şerit noktaları Hough dönüşümü ile elde edilmektedir. Olası bozucu etkileri elemek amaciyla elde edilen aday noktaları üzerinde giriş görüntüsü ile 1-boyutlu korelasyon işlemi uygulanmaktadır. Korelasyon işlemi sonrası belirlenen aday şerit noktaları üzerinde RANSAC [9] çalıştırılarak şerit çizgileri tespit edilmektedir. Yöntemde şerit çizgilerinin tespit edilen konumları arasında Kalman filtresi [10] yardımıyla zamansal ilişki kurularak olası hataların önüne geçilmesi amaçlanmaktadır. Espinoza ve Torritti'nin [11] önerdiği yaklaşımda öncelikle yol alanı belirlenerek sonraki işlemlerin sadece bu alan üzerinde uygulanması sağlanmaktadır. Yol alanı çıkartım işlemi Gabor dokusal özellikler (Gabor textural features) ve ortalama-kaydırma kümelemesi (mean-shift clustering) kullanılarak gerçekleştirilmektedir. Şerit çizgileri sırasıyla yönlendirmeli filtre (steerable filter), IPM, Hough dönüşümü ve MSAC (M-estimator Sample and Consensus) [12] yöntemlerinin kullanılması ile tespit edilmektedir. Şerit çizgileri tespit başarımı genişletilmiş Kalman filtresi (extended Kalman filter) kullanılarak iyileştirilmektedir. Iş̧1klandırma (illumination) koşulları, görüntü işleme tabanlı yöntemlerde sistem başarımını etkileyen en önemli etkenlerden biridir.

Yoo, vd. [13] 1şıklandırma etkisine karşı gürbüz çalışabilen doğrusal ayırgaç analizi (linear discriminant analysis - LDA) tabanlı gradyen iyileştirme yaklaşımını önermektedir. Bu yöntemde şerit çizgilerinin yol yüzeyinden ayrılması için şerit çizgileri üzerindeki gradyenlerin maksimum hale getirilmesi amaçlanmaktadır. RGB renk kanal ağırlıkları uygun bir şekilde oluşturularak maksimum gradyenler elde edilmektedir. Şerit çizgileri LDA tabanlı dönüşüm sonrası Canny kenar tespiti, Hough dönüşümü ve eğri model uydurma işlemleri ile elde edilmektedir. Gece zamanlarında, şerit işaretlerini tespit etmek gündüz zamanlarına göre genel olarak daha zordur. $\mathrm{Bu}$ durumun temel sebebi 1 şık seviyesinin düşük olması nedeniyle kameradan alınan görüntülerde ortalama 1şıklılık değerlerinin gündüz zamanlarında elde edilen görüntülere göre daha düşük olmasıdır. Işık seviyesinin düşük olduğu durumlarda şerit tespiti için You vd. [14] tarafindan önerilen yaklaşımın ön işlem adımında ortalama filtreleme, 8-yönlü Sobel operatörü ve Otsu [15] eşikleme işlemleri bulunmaktadır. Eşiklenmiş görüntü üzerinde piksel dağılımları incelenerek aday şerit noktaları tespit edilmektedir. $\mathrm{Bu}$ inceleme kapsamında bir pikselin komşuları ile ilişkisi farklı yönler için genel olarak aynıysa bu nokta aday şerit noktası olarak elde tutulurken, diğer pikseller gürültü olarak değerlendirilip elenmektedir. Sonraki adımda sadece aday şerit noktalarını içeren görüntüye Hough dönüşümü uygulanarak şerit çizgileri elde edilmektedir. Mammeri vd. [16], MSER (Maximally Stable Extremal Regions) [17] ve Hough dönüşüm tabanlı bir şerit 
tespit yaklaşımı önermiştir. İlk olarak olası şerit alanları MSER ile elde edilmektedir. Üç aşamalı bir arıtma (refinement) algoritması ile istenmeyen alanlar elenmektedir. Arıtma işlemi sonrasında kalan alanlar üzerinden özellik noktaları elde edilmektedir. Bu özellik noktalar1 kullanılarak PPHT (Progressive Probabilistic Hough Transform) [18] ile şerit çizgileri tespit edilmektedir. Son olarak tespit edilen şerit çizgileri Kalman filtresi kullanılarak takip edilmektedir. Arıtma algoritmasının kullanılması yöntemin gerçek zamanlı çalışmasını sağlamakla birlikte birçok yanlış tespite de neden olmaktadır. Küçükyıldız ve Ocak'ın [19] önerdiği yöntem bir DSP (Digital Signal Processor) üzerinde gerçek zamanlı çalışmaktadır. Bu yöntemin ön işlem aşamasında dikey 1boyutlu Sobel filtresi ve eşikleme uygulanmaktadır. Sonrasında Hough dönüşümü ile görüntü üzerindeki çizgiler tespit edilmektedir. Tespit edilen çizgilerin sadece başlangıç ve bitiș noktalarının IPM dönüşümü sonrası şerit genişliği ve paralellik temelli bir metrik eleme işlemi uygulanmaktadır. Eleme işlemi sonrası şerit çizgileri elde edilmektedir. Shin vd. [20] tarafindan önerilen yöntemde ilk olarak giriş görüntülerinin 4-noktalı eğme perspektif yöntemi (4-points warp perspective method) ile elde edilmiş kuşbakışı görüntüleri üzerinde dikey kenar tespiti ve Öklid temelli yönlü uzaklık haritası oluşturma işlemleri uygulanmaktadır. Ön işlem sonrası elde edilen yönlü uzaklık haritasının satır bilgileri analiz edilerek süperparçacık filtresi (superparticle filter) ile şerit çizgileri tespit edilmektedir. Ayrıca tespit edilen şerit konumlarının çerçeveler arası ilişkisi de takip edilmektedir. Önerilen yöntem gece, gündüz ve yağmur gibi farklı ve zorlayıcı senaryolarda test edilmiştir. Yakın zamanlarda yayınlanan şerit tespit yöntemlerinin karşılaştırılması Tablo 1'de verilmektedir. Bu tabloda, ön işlem, özellik çıkartımı ve son işlem aşamalarında kullanılan yöntemler, bu yöntemlerin uygulandığı veri tabanları ile yöntemlerin başarımının değerlendirilmesinde kullanılan metrikler, işlem hızları ve yöntemler hakkında genel tespitler verilmektedir.

\section{2. ŞERITT TESPITİ (LANE DETECTION)}

Önerilen şeritten ayrılma uyarı sistemi üç aşamadan oluşmaktadır. İlk adımda şerit işareti filtresi ve eşikleme işlemleri ile şerit çizgileri öne çıkarılmaktadır. Eşiklenmiş görüntü üzerindeki konumlarda giriş görüntüsüne Gauss fonksiyonu tabanlı bir korelasyon işlemi uygulanarak aday şerit noktaları tespit edilmektedir. Sonraki adımda aday şerit noktalarından belirli bir karakteristiğin dışındakiler RANSAC yöntemiyle elenerek şerit çizgileri tespit edilmektedir. Tespit edilen şerit çizgilerinin konumları arasındaki zamansal ilişki Kalman filtresi ile incelenerek olas1 hatalı tespitlerin önüne geçilmektedir. Önerilen sistemin akış diyagramı Şekil 1'de gösterilmektedir.

\section{1. Ön İslem (Pre-Processing)}

Bu çalışmada hesapsal yükü azaltmak amacıyla kameradan alınan görüntünün bütün olarak incelenmesi yerine, sadece yol bilgisini içeren belirli bir kısmı incelenmektedir. $\mathrm{Bu}$ doğrultuda işlemler sadece bir ilgi alanı (region of interest -
ROI) üzerinde gerçekleştirilmektedir. Şekil 2'de örnek bir ROI gösterilmektedir. Bu ilgi alanı sistemin ilk kurulum aşamasında bir kalibrasyon işlemi ile sabit pozisyon ve büyüklükte olacak şekilde belirlenmektedir. İlgi alanı tekrar kurulum yapılmadığı sürece değişmemektedir. Kameralardan alınan yol görüntülerdeki şerit işaretlerinin yapıları yoldaki yansımalar, işaretlerin zamanla aşınması, gölge ve hava şartları gibi nedenlerden bozulabilmektedir. Şerit tespit işlemlerinin bu gibi olumsuz durumlardan daha az etkilenmesini sağlamak amaciyla Nieto vd.'nin [21] çalışmasında kullanılan ve Eş. 1'de verilen şerit işareti filtresi kullanılmaktadır. Bu denklemdeki $\mathrm{T}$ şerit çizgisinin kalınlığını, $x$ giriş imgesini, $y$ çıkış imgesini, $i$ ise piksel pozisyonunu göstermektedir.

$y_{i}=2 x_{i}-\left(x_{i-T}+x_{i+T}\right)-\left|x_{i-T}-x_{i+T}\right|$

Giriş görüntüsü gri-seviyeli görüntüye dönüştürülerek şerit işareti filtresi uygulanmaktadır. Şekil 3'te CalTech [22] şerit veri tabanından alınan örnek bir yol görüntüsü ve şerit işareti filtresi çıkışı gösterilmektedir. Şerit işareti filtresi sonuç görüntüsü Otsu yöntemiyle elde edilen eşik değerine göre ikili (binary) görüntüye dönüştürülür. Elde edilen ikili görüntü ile görüntü üzerinde işlem yapılan nokta sayısının azaltılması amaçlanmaktadır. Şekil 4'te, Şekil 3(b)'deki şerit işareti filtresi görüntüsünün eşikleme işlemi sonucu gösterilmektedir.

\section{2. Özellik Çıkartımı (Feature Extraction)}

Şerit çizgilerinin elde edilmesi için kullanılacak öznitelik bilgileri bu aşamada elde edilmektedir. Şerit işareti öznitelikleri, ön işlem aşamasında elde edilen eşiklenmiş görüntü üzerinden çıkarılmaktadır. Eşiklenmiş görüntü üzerinde eşik değeri aşan her bir nokta şerit işaretlerinin tespitinde kullanılacak aday şerit işareti konumudur. Gri-seviyeli giriş görüntüsü üzerinde bu noktalar analiz edilerek şerit işaretlerinin tespitinde kullanılabilecek aday şerit işareti öznitelikleri elde edilmektedir. Analiz işleminde şerit işareti aday noktalarının gri-seviyeli görüntüde karşılık geldiği nokta ve çevresinin yatay eksendeki değerleri incelenmektedir. Örnek bir şerit işareti görüntüsü Şekil 5(a)'da verilmektedir. Şekil 5(b)'de ise bu görüntünün piksel değerleri yatay ve dikey pozisyonuna göre 3-boyutlu şekilde görselleştirilmiştir. Şekil 5(a) ve Şekil 5(b)'de gösterilen şerit işareti görüntüsünün 45. satırının piksel değerleri Şekil 5(c)'de 1-boyutlu olarak görselleştirilmiştir. Aynı şekil üzerinde 1-boyutlu belirli bir $\mu$ ve $\sigma$ değerine sahip Gauss dağılımlı bir fonksiyon da gösterilmiştir. Bu şekilden şerit bölgesinin 1-boyutlu incelenmesi durumunda elde edilen işaretin Gauss biçimli bir yapıya sahip olduğu açıç̧a görülmektedir. Dolayısıyla gri-seviyeli görüntü üzerindeki bir piksel konumu şerit işaretine ait bir konumda ise bu konumu merkez alan piksel değerleri 1-boyutlu Gauss fonksiyonu ile benzer bir yapı göstermelidir. Bu durumun tespiti amacıyla önerilen yöntemde aday şerit işareti noktalarını merkez alacak şekilde alınan 1-boyutlu kesitler ile daha önceden tanımlı sabit boyutlu bir 1-boyutlu Gauss fonksiyonu korelasyon işlemine tabi tutulur. 
Tablo 1. Yakın zamanda önerilen şerit tespit yöntemlerinin karşılaştırılması (Comparison of recent lane detection methods)

\begin{tabular}{|c|c|c|c|c|c|c|}
\hline Yöntem & Ön İşlem & $\begin{array}{l}\text { Özellik } \\
\text { Çıkartımı }\end{array}$ & Son İşlem & $\begin{array}{l}\text { Platform } \\
/ \mathrm{Hzz} \\
\text { (fps) }\end{array}$ & Veritabanı & Tespitler \\
\hline $\begin{array}{l}\text { Borkar vd. } \\
\text { [7] (2012) }\end{array}$ & $\begin{array}{l}\text { Zamansal } \\
\text { bulanıklaştırma, } \\
\text { Adaptif eşikleme, } \\
\text { IPM }\end{array}$ & $\begin{array}{l}\text { Hough } \\
\text { dönüşümü, } \\
\text { Gauss şablon } \\
\text { eşleştirme }\end{array}$ & $\begin{array}{l}\text { RANSAC, } \\
\text { Kalman } \\
\text { filtresi }\end{array}$ & $\begin{array}{l}\mathrm{PC} / \\
1.25\end{array}$ & $\begin{array}{l}\text { Kendi } \\
\text { veritabanlar1 }\end{array}$ & $\begin{array}{l}\text { Bu çalışma genel olarak başarılı sonuçlar } \\
\text { vermesine karşı ana problemi hesapsal } \\
\text { yüküdür. Ayrıca sistem performansı hız } \\
\text { tümsekleri ve 1şıklılık değişimlerinden } \\
\text { etkilenebilmektedir. }\end{array}$ \\
\hline $\begin{array}{l}\text { You vd. } \\
\text { [14]. } \\
(2013)\end{array}$ & $\begin{array}{l}\text { Komşuluk } \\
\text { ortalama } \\
\text { filtreleme, } \\
\text { 8-yönlü Sobel } \\
\text { operatörü, Otsu } \\
\text { eşikleme, } \\
\text { İgi alanı }\end{array}$ & $\begin{array}{l}\text { Piksellerin } \\
\text { dağılımı } \\
\text { (gradyen, } \\
\text { 1şılkllık), Hough } \\
\text { dönüşümü }\end{array}$ & - & PC / 17 & $\begin{array}{l}\text { Kendi } \\
\text { veritabanları }\end{array}$ & $\begin{array}{l}\text { Komşuluk ortalama filtresi gürültüleri } \\
\text { azaltmada etkilidir. Sobel operatörünün } \\
\text { farklı yönlerde uygulanması kenar tespit } \\
\text { başarımını artırmıştır. }\end{array}$ \\
\hline $\begin{array}{l}\text { oo vd. } \\
\text { [13]. } 2013\end{array}$ & $\begin{array}{l}\text { LDA temelli } \\
\text { gradyen } \\
\text { iyileştirme, } \\
\text { Adaptif Canny } \\
\text { kenar tespiti, }\end{array}$ & $\begin{array}{l}\text { Hough } \\
\text { dönüşümü, } \\
\text { kenar-bağlama } \\
\text { yöntemi }\end{array}$ & $\begin{array}{l}\text { Clothoid eğri } \\
\text { modeli ile } \\
\text { çizgi uydurma }\end{array}$ & $\mathrm{PC} / 20$ & $\begin{array}{l}\text { Kendi } \\
\text { veritabanları }\end{array}$ & $\begin{array}{l}\text { Bu çalışmada kullanılan LDA temelli filtre } \\
\text { ile farklı 1şıklılık koşullarında şerit çizgileri } \\
\text { üzerinde güçlü kenar bilgileri elde } \\
\text { edilmiştir. Ama aynı sahne için birden fazla } \\
\text { 1şıklılık içeren durumarda (su yansıması } \\
\text { vb.) sistem performansı düşmektedir. }\end{array}$ \\
\hline $\begin{array}{l}\text { Espinoza ve } \\
\text { Torriti } \\
{[11]} \\
(2013)\end{array}$ & $\begin{array}{l}\text { Ortalama- } \\
\text { kaydırma } \\
\text { kümeleme, Gabor } \\
\text { ve GMRF dokusal } \\
\text { özellikler }\end{array}$ & $\begin{array}{l}\text { Yönlendirmeli } \\
\text { filtreler, IPM, } \\
\text { Hough } \\
\text { dönüşümü }\end{array}$ & $\begin{array}{l}\text { Clothoid model } \\
\text { denklemleri, } \\
\text { MSAC, } \\
\text { Genişletilmiş } \\
\text { Kalman filtresi }\end{array}$ & $\mathrm{PC} / 5.6$ & $\begin{array}{l}\text { Kendi } \\
\text { veritabanları } \\
\text { (Yer doğrusu } \\
\text { elle } \\
\text { oluşturulmuş) }\end{array}$ & $\begin{array}{l}\text { Önerilen sistemde sadece yol alanı } \\
\text { üzerinde çalışılması şerit işaretleri tespiti } \\
\text { için işlenmesi gereken alanı azalttığından } \\
\text { olası hatalı tespitlerin önüne geçerek sistem } \\
\text { performansını iyileştirmektedir. Yol alanı } \\
\text { tespitinin getirdiği ek hesapsal yük ile } \\
\text { sistem performansı iyileştirmesi arasında } \\
\text { bir tercih yapılması gerekmektedir. }\end{array}$ \\
\hline $\begin{array}{l}\text { Küçükyıldız } \\
\text { ve Ocak } \\
\text { [19] } \\
(2014)\end{array}$ & $\begin{array}{l}\text { Dikey 1-D Sobel } \\
\text { filtresi, Eşikleme }\end{array}$ & $\begin{array}{l}\text { Hough } \\
\text { dönüşümü, } \\
\text { IPM }\end{array}$ & $\begin{array}{l}\text { Metrik analiz } \\
\text { (Şerit } \\
\text { genişliği) }\end{array}$ & $\begin{array}{l}\text { Gömülü } \\
\text { / } 30\end{array}$ & $\begin{array}{l}\text { CMU } \\
\text { (Carneigh } \\
\text { Mellon } \\
\text { University) }\end{array}$ & $\begin{array}{l}\text { Bu çalışmada hesapsal yükü azaltacak } \\
\text { yöntemler önerilmektedir. Önerilen } \\
\text { yaklaşımın performans sonuçları bir } \\
\text { veritabanı üzerinde değerlendirilmemiştir. } \\
\text { Bunun yerine giriş görüntüsünün farklı } \\
\text { SNR seviyelerinde tespit başarımı } \\
\text { incelenmiştir. }\end{array}$ \\
\hline $\begin{array}{l}\text { Gaikwad ve } \\
\text { Lokhande } \\
\text { [5] } \\
(2015)\end{array}$ & ROI, PLSF & $\begin{array}{l}\text { Hough } \\
\text { dönüşümü }\end{array}$ & $\begin{array}{l}\text { Öklid } \\
\text { uzaklığg }\end{array}$ & $\mathrm{PC} / 28$ & $\begin{array}{l}\text { Kendi } \\
\text { veritabanları, } \\
\text { LabelMe } \\
\text { veritabanı }\end{array}$ & $\begin{array}{l}\text { PLSF ön işlemi şerit tespit işlemini } \\
\text { kolaylaştırmasına karşın parametrelerinin } \\
\text { farklı yol senaryolarına göre değiştirilmesi } \\
\text { gerekliliği sistem performansı etkileyen en } \\
\text { büyük problemdir. }\end{array}$ \\
\hline $\begin{array}{l}\text { Shin vd. } \\
{[20]} \\
(2015)\end{array}$ & $\begin{array}{l}\text { Kuşbakışı görüntü, } \\
\text { Dikey kenar } \\
\text { tespiti, yönlü } \\
\text { uzaklık dönüşümü }\end{array}$ & $\begin{array}{l}\text { Satır işlemleri, } \\
\text { Süper parçacık } \\
\text { filtresi }\end{array}$ & $\begin{array}{l}\text { Zamansal } \\
\text { ilişki }\end{array}$ & $\mathrm{PC} / 16$ & $\begin{array}{l}\text { CalTech } \\
\text { veritabanı, } \\
\text { Georgia } \\
\text { veritabanı }\end{array}$ & $\begin{array}{l}\text { Bu çalışmada önerilen parçacık filtresini } \\
\text { diğer çalışmalara göre öne çıaran birden } \\
\text { fazla parçacık filtresinin birleştirilmesinden } \\
\text { oluşmasıdır. Ayrıca bu filtreyle literatürde } \\
\text { bulunan çalışmalara etkisi de incelenmiştir. } \\
\text { Filtrenin başarımı farklı yol durumlarında } \\
\text { test edilmiştir. }\end{array}$ \\
\hline $\begin{array}{l}\text { Mammeri } \\
\text { vd. [16] } \\
(2016)\end{array}$ & MSER & $\begin{array}{l}\text { MSER aritma, } \\
\text { tarama } \\
\text { algoritmas1, } \\
\text { PPHT }\end{array}$ & $\begin{array}{l}\text { Kalman } \\
\text { filtresi }\end{array}$ & $\mathrm{PC} / 24$ & $\begin{array}{l}\text { Kendi } \\
\text { veritabanları }\end{array}$ & $\begin{array}{l}\text { Bu çalışmada MSER yöntemi ile giriş } \\
\text { görüntüsü üzerindeki şerit çizgileri de dahil } \\
\text { özellik bölgeleri başarılı bir şekilde tespit } \\
\text { edilmektedir. Bu bölgelerden şerit } \\
\text { çizgilerinin tespitinde kullanılan arıtma } \\
\text { yöntemi önerilen sistemin en zayıf noktası } \\
\text { olarak yanlış tespitlere neden } \\
\text { olabilmektedir. Öte yandan arıtma } \\
\text { yönteminin basit olması yöntemin gerçek- } \\
\text { zamanlı çalışmasını sağlamaktadır. }\end{array}$ \\
\hline
\end{tabular}




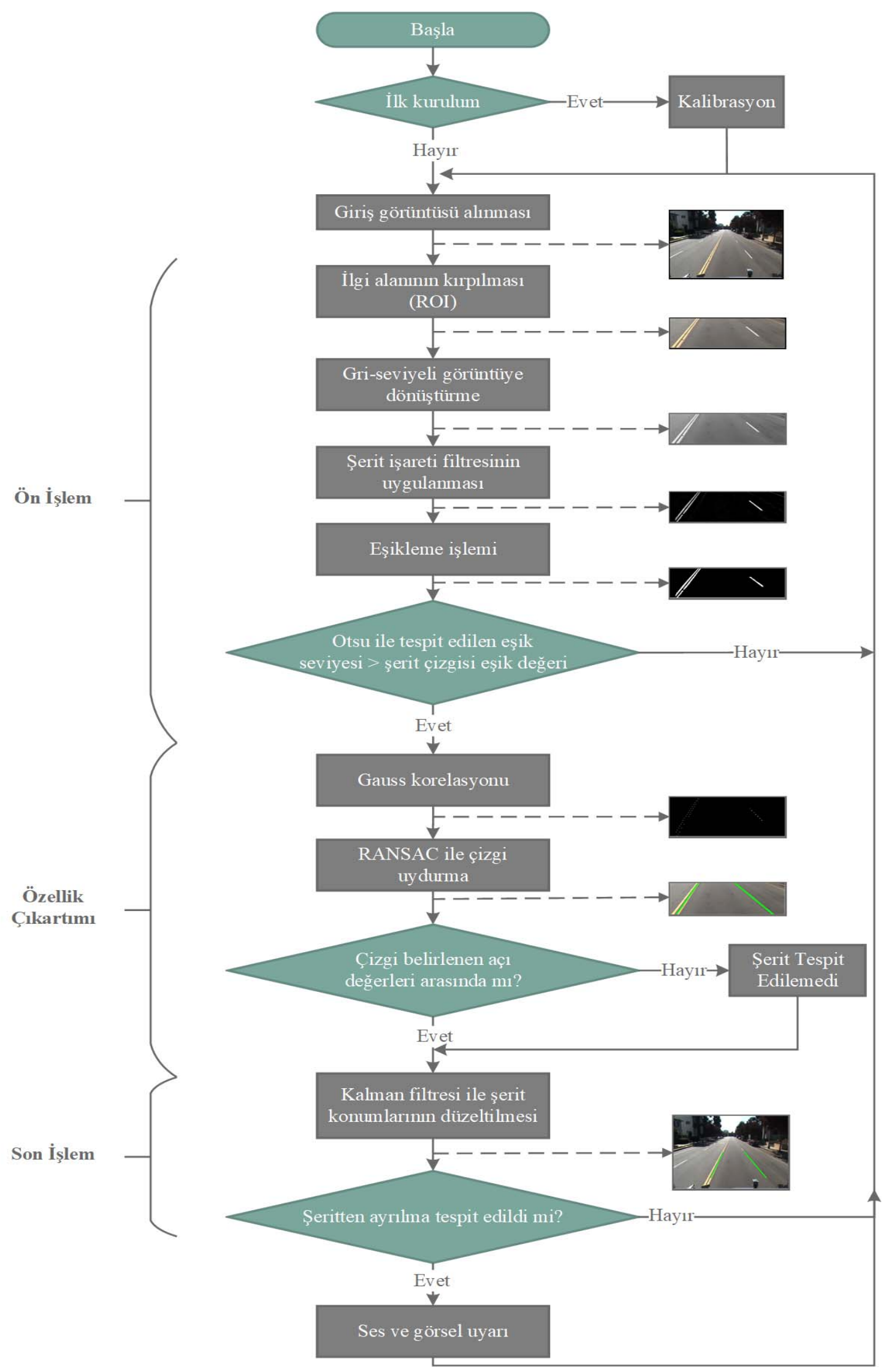

Şekil 1. Önerilen sistemin akı̧̧ diyagramı (Flowchart of the proposed method) 


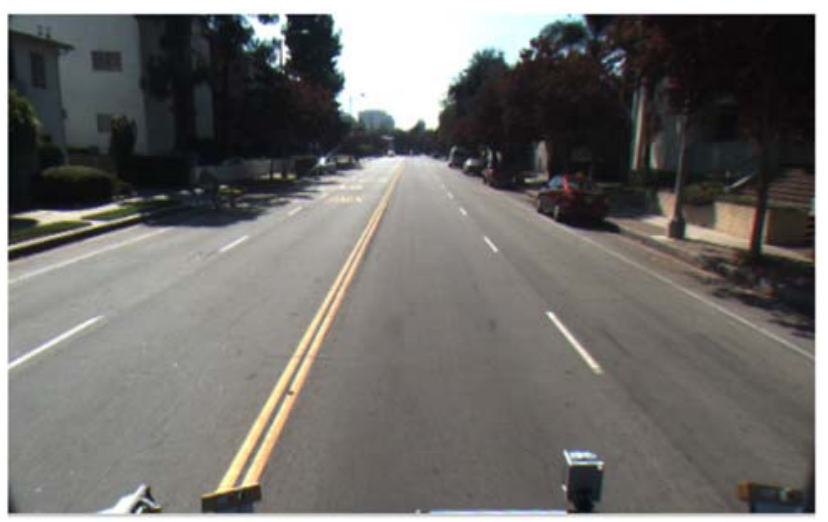

(a)

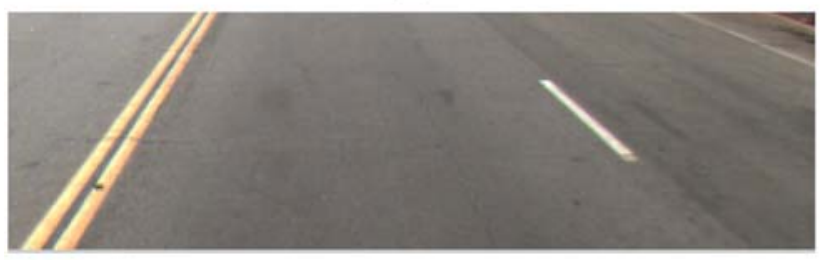

(b)

Şekil 2. İlgi alanı a) Giriş görüntüsü b) İlgi alanı (Region of interest a) Input image b) Region of interest)

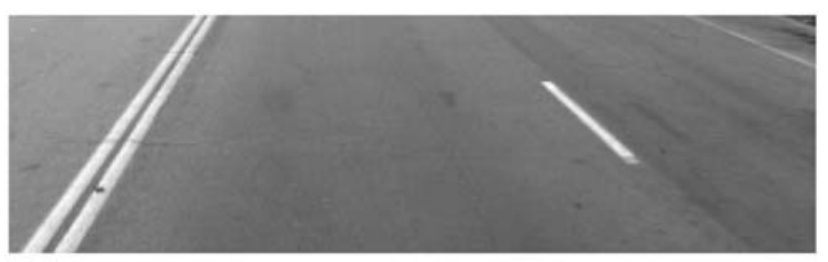

(a)

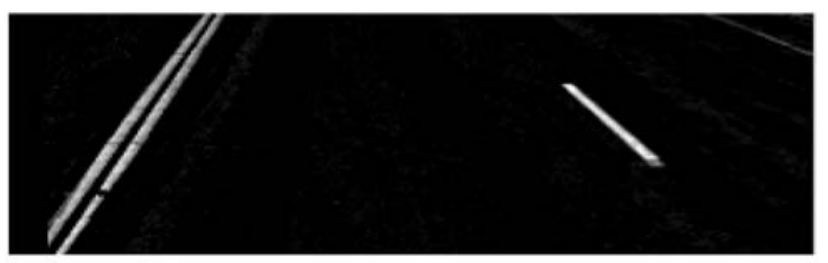

(b)

Şekil 3. Şerit işareti filtresi a) Gri-seviyeli giriş görüntüsü b) Şerit işareti filtresi sonucu (Lane marking filter (a) Gray-scale input image (b) Lane marking filter result)

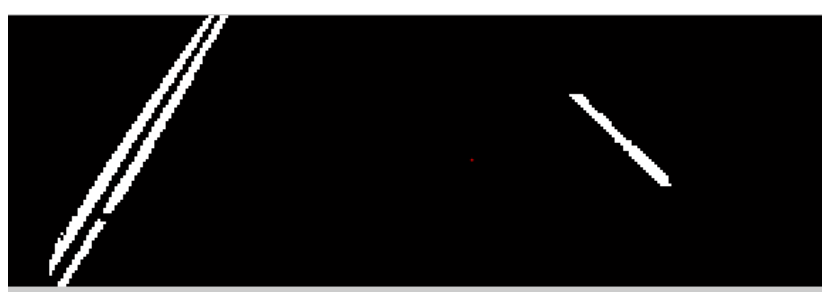

Şekil 4. Eşikleme işlemi sonucu (Thresholding result)

Korelasyon seviyesi belirlenen sabit bir eşik değerinden düşük olan aday şerit işareti konumları elenerek kalan şerit işareti özellik noktaları tespit edilmektedir. Şekil 6'da, yukarıda açıklanan tespit yaklaşımı ile Şekil 2(b)'deki giriş görüntüsü için elde edilen şerit işareti özellik noktaları gösterilmektedir.

\subsection{Son İşlem (Post-Processing)}

Özellik çıkartımı aşamasında elde edilen şerit işareti özellik noktalarının tamamı şerit işaretlerinin üzerinde olmayabilir. Işıklılık, hava durumu, yol yapısındaki bozukluklar vb. olumsuz durumlarda kameradan alınan görüntüde şerit işareti olmayan bölgelerde hatalı olarak özellik noktaları tespit edilebilmektedir. $\mathrm{Bu}$ bozucu özellik noktalarının (outliers) elenmesi ve şerit işaretlerinin başarılı bir şekilde tespit edilebilmesi için RANSAC yöntemi kullanılmaktadır. Böylelikle şerit çizgilerinin doğru biçimindeki yapısına uymayan bozucuların şerit çizgisi tespitine etkisi ortadan kaldırılmaktadır. RANSAC yöntemiyle Şekil 6'da gösterilen şerit işareti özellik noktalarının değerlendirilmesi sonucu elde edilen şerit çizgileri ROI ve kameradan alınan orijinal görüntü üzerinde Şekil 7'de gösterilmektedir.

Kameradan alınan görüntü üzerinde anlık oluşabilecek 1şıklılık değişimi, gürültü vb. durumlar şerit işareti tespit performansını olumsuz etkileyebilmektedir. Bu çalışmada, bu olası sorunu önlemek amacıyla tespit edilen şerit işareti konumlarının çerçeveler arası ilişkisi Kalman filtresi işlenmektedir. Kalman filtresi bir sistem için durum tahmini gerçekleştirmektedir. Bu tahmin için sistemin süreç ve ölçüm gürültüsünden faydalanmaktadır. Süreç ve ölçüm gürültüsü sıfır ortalamalı Gauss dağılımlı varsayılmaktadır. $\mathrm{Bu}$ çalışmada Kalman filtresi sabit hızlanma (constant acceleration) modeli ile kullanılmaktadır. Eş. 2 ve Eş. 3 'te Kalman filtresinin doğrusal dinamik sistem formu verilmektedir [23, 24].

$\left[\begin{array}{c}x(n) \\ y(n) \\ v_{x}(n) \\ v_{y}(n) \\ a_{x}(n) \\ a_{y}(n)\end{array}\right]=\left[\begin{array}{cccccc}1 & 0 & \Delta t & 0 & \frac{\Delta t^{2}}{2} & 0 \\ 0 & 1 & 0 & \Delta t & 0 & \frac{\Delta t^{2}}{2} \\ 0 & 0 & 1 & 0 & \Delta t & 0 \\ 0 & 0 & 0 & 1 & 0 & \Delta t \\ 0 & 0 & 0 & 0 & 1 & 0 \\ 0 & 0 & 0 & 0 & 0 & 1\end{array}\right]\left[\begin{array}{c}x(n-1) \\ y(n-1) \\ v_{x}(n-1) \\ v_{y}(n-1) \\ a_{x}(n-1) \\ a_{y}(n-1)\end{array}\right]+N(0, Q)$

$\left[\begin{array}{l}x_{\text {gözlem }}(n) \\ y_{\text {gözlem }}(n)\end{array}\right]=\left[\begin{array}{llllll}1 & 0 & 0 & 0 & 0 & 0 \\ 0 & 1 & 0 & 0 & 0 & 0\end{array}\right]\left[\begin{array}{l}x(n) \\ y(n) \\ v_{x}(n) \\ v_{y}(n) \\ a_{x}(n) \\ a_{y}(n)\end{array}\right]+N(0, R)$

$\mathrm{Bu}$ eşitliklerde $x(n)$ ve $y(n)$ yatay ve düşey düzlemdeki konum vektörlerini, $\Delta t$ zamandaki değişimi, $v_{x}(n)$ ve $v_{y}(n)$ hızdaki değişimi, $a_{x}(n)$ ve $a_{y}(n)$ ise ivmedeki değişimi 


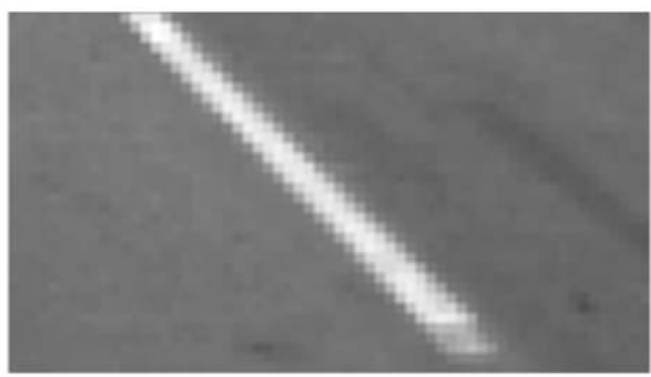

(a)

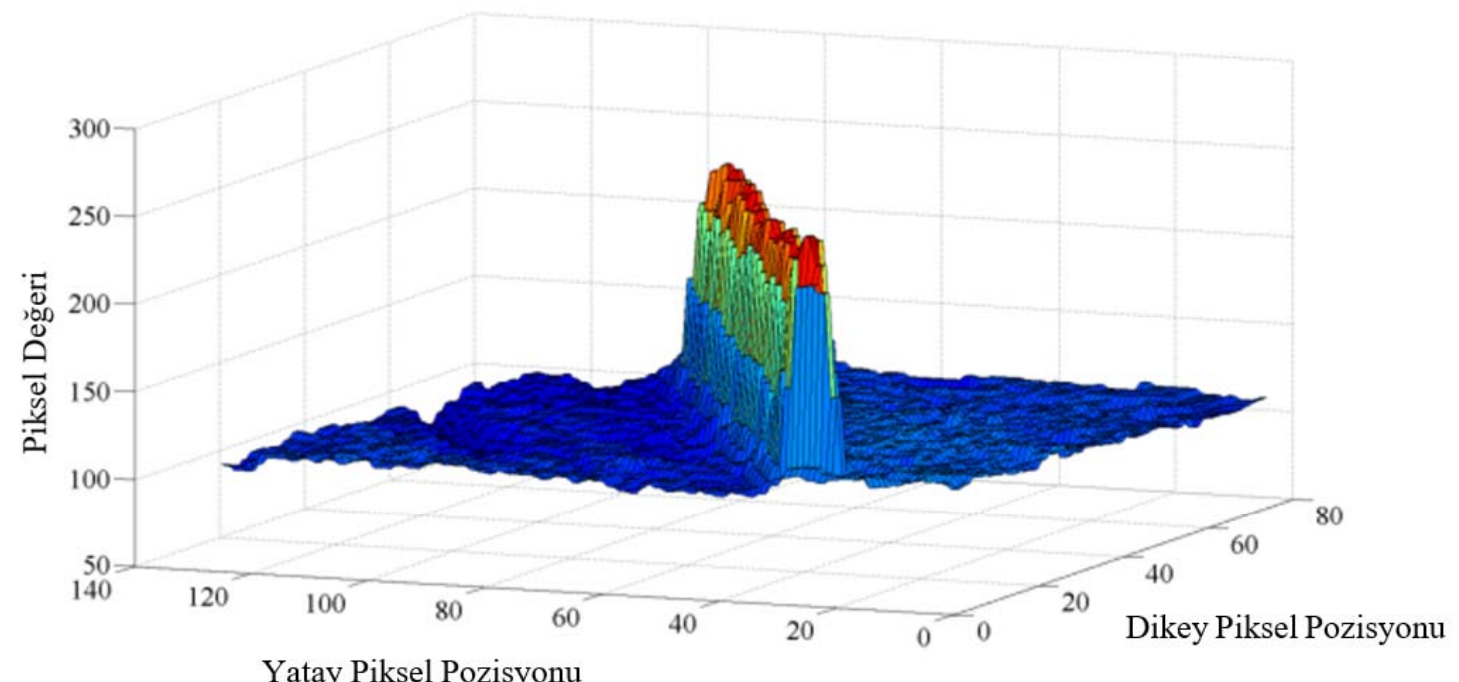

(b)

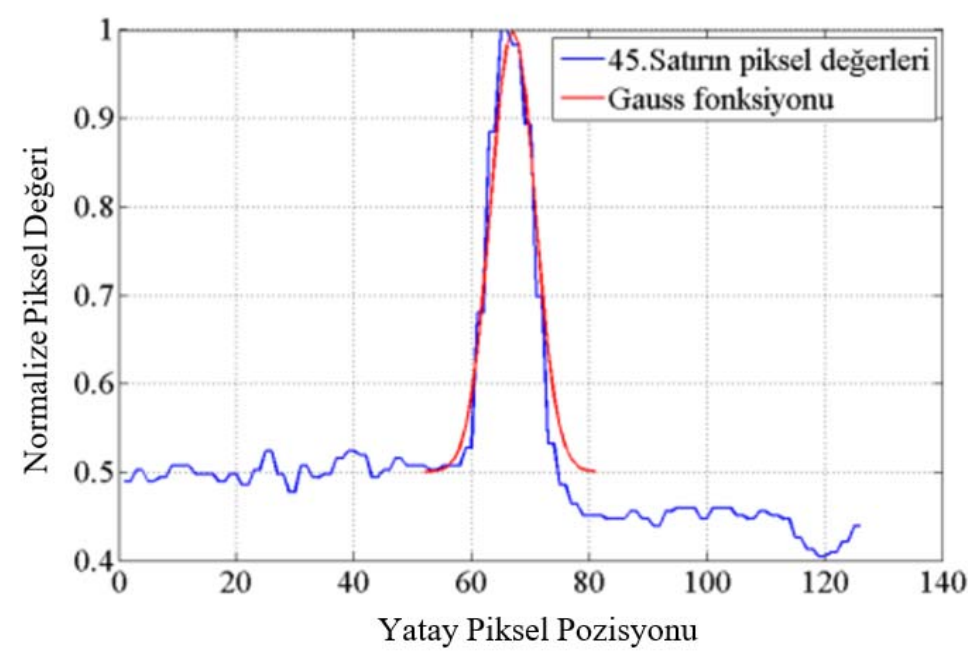

(c)

Şekil 5. Şerit işareti üzerindeki piksel dağılımı a) Şerit işareti b) Şerit işaretinin 3-B gösterimi c) Şerit işaretinin 1-B piksel gösterimi ve Gaussian fonksiyonu (Pixel distribution on the lane marking a) Lane marking b) 3-D representation of lane markings c) 1-D representation of lane marking and Gaussian function)

göstermektedir. Gözlem sonuçları olan $x_{\text {gözlem }}(n)$ ve ygözlem $(n)$ Kalman filtresinin hataya bağlı olarak güncellenmesinde kullanılmaktadır. Bu eşitliklerde süreç ve ölçüm gürültüleri birbirinden bağımsız ve normal olasılık dağılımlı olacak şekilde $N(0, Q)$ ve $N(0, R)$ ile gösterilmiştir. Kalman filtresi ile tespit edilen şerit çizgilerinin başlangıç ve bitiş noktaları kullanılarak yeni başlangıç ve bitiş noktaları elde edilmektedir. Elde edilen bu başlangıç ve bitiş noktaları ile yeni çizgiler oluşturulmaktadır. Bu çizgiler son şerit işareti çizgileri olarak değerlendirilmektedir. Şekil 8'de örnek bir şerit çizgisi konumları ve Kalman filtresi sonuçları verilmektedir. $\mathrm{Bu}$ grafikte kırmızı renk ile gösterilen 
konumlar tespit edilen şerit çizgisi konumlarını, mavi renk ile gösterilen ise bu konumların Kalman filtresi ile işlenmesi sonucunda elde edilen sonuç şerit çizgisi konumunu göstermektedir. Şekil 8'de "1" ile etiketlenen yerler şerit çizgilerinin tespit edilemediği yerleri göstermekte olup bu durumda tespit edilen şerit pozisyonu 0 olarak gösterilmiştir. "2" numaralı yerler ise şerit çizgisi tespit edilemeyen durumlarda Kalman filtresi ile tahmin edilen şerit çizgisi konumlarını belirtmektedir. Şekil 8'den anlaşılacağı üzere anlık olarak şerit çizgisi tespit edilemediği durumlarda Kalman filtresinin kullanılması ile şerit tespit performansı iyileştirilmektedir.

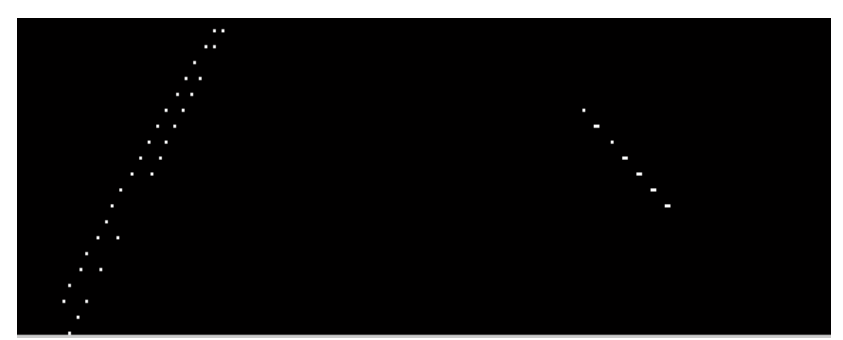

Şekil 6. Tespit edilen şerit işareti özellik noktaları (Detected lane marking feature points)

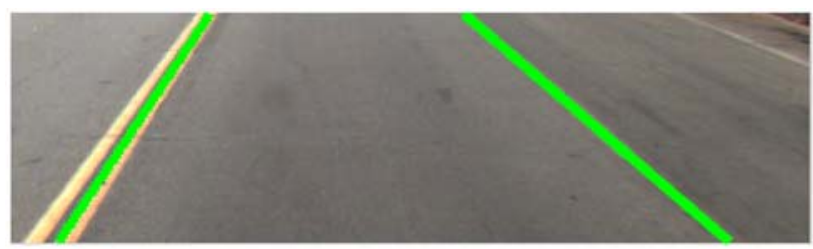

(a)

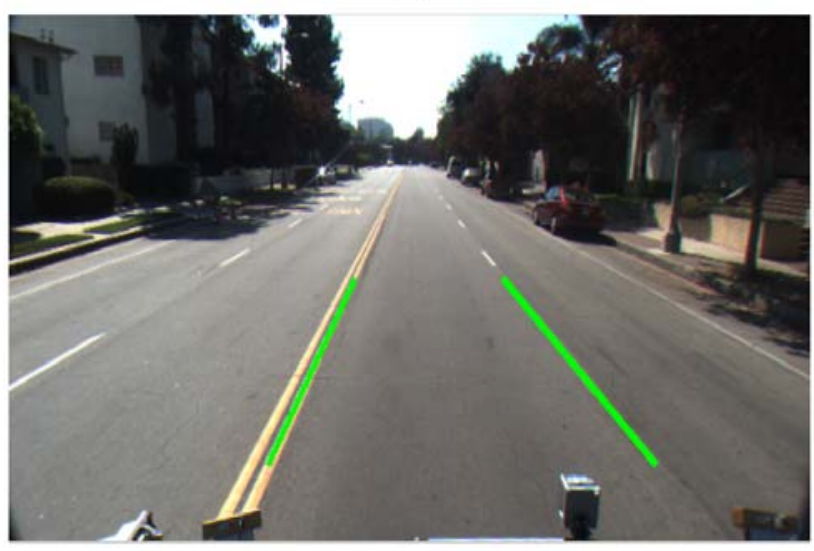

(b)

Şekil 7. Tespit edilen şerit işaretleri a) ROI üzerinde tespit sonucu b) Orijinal görüntü üzerinde tespit sonucu

(Detected lane markings a) Detection result on the ROI b) Detection result on the original image)

\section{3. ŞERITTEN AYRILMA TESPITI (LANE DEPARTURE DETECTION)}

Bir aracın şeritlerle bölünmüş yol üzerinde Şekil 9'da gösterildiği gibi üç farklı seyir durumu bulunmaktadır. İçinde bulunduğu şerit çizgileri arasındaki seyir hali normal seyir (Şekil 9(b)), sağ şerit çizgisi üzerinden geçerek diğer
Şerit bölgesine geçmesi sağ şerit değişikliği (Şekil 9(c)), sol şerit çizgisi üzerinden geçerek şerit değiştirmesi ise sol şerit değişikliği olarak adlandırılmaktadır (Şekil 9(a)). Bu çalışmada normal seyir halinde bulunan araçların şerit değiştirmeleri tespit edilerek sürücüye bildirilmesi sağlanmaktadır. Bu doğrultuda geliştirilen sistemde araç konumu ve şerit konumları gerçek zamanlı olarak yorumlanarak varsa uyarı durumu tespit edilmektedir. Bu amaçla aracın ön tekerleklerinin dış konumunun görüntü yüzeyindeki izdüşümü ile şerit çizgileri konumunun arasındaki uzaklığın $30 \mathrm{~cm}$ 'den az olması durumunda şerit değişikliği kararı verilmektedir. Bu mesafe 351/2012 sayılı Avrupa Birliği Komisyonu tarafindan hazırlanan Motorlu Araçlara Şeritten Ayrılma Uyarı Sistemi takılması yönetmeliğinde belirtilen çerçevede belirlenmiştir. Şerit değişikliği kararlarının gerçek dünya mesafeleri (metrik veriler) üzerinden tespit edilebilmesi için öncelikli olarak önerilen sistemin kalibrasyonu gerekmektedir. Bu kalibrasyon işleminde şerit genişliği, şerit çizgileri arası genişlik ve aracın ön tekerlek lastiklerinin diş kısımları arasındaki uzaklık bilgileri kullanılmaktadır. Şekil 10'da kalibrasyon için gerekli parametre bilgileri gösterilmektedir. Bir pikselin metrik karşılı̆̆ Eş. 4'te verildiği gibi hesaplanmaktadır. $\mathrm{Bu}$ dönüşüm sırasında işlemleri basitleştirmek için ROI'nin orta noktası kullanılmakta olup böylelikle perspektif etkisi hesaba dahil edilmemiştir.

piksel2cm $=\frac{\text { Şerit Genişliği }(\mathrm{cm})}{\text { Tespit Edilen Şerit İşaretleri Arası Genişlik (piksel) }}$

\section{GÖMÜLÜ PLATFORM UYGULAMASI (EMBEDDED PLATFORM IMPLEMENTATION)}

Bu çalışma kapsamında önerilen ve detayları Bölüm 2 ve 3'te detayları açıklanan şeritten ayrılma uyarı sistemi öncelikle bilgisayar ortamında MATLAB platformunda geliştirilmiştir. Bu görüntü işleme yöntemi daha sonra Tablo 2'de verilen sistem özelliklerine sahip bir gömülü platforma birebir uygulanıp gerçek zamanlı olarak gömülü platform üzerinde gerçekleştirilmiştir.

Tablo 2. Gömülü platform özellikleri

(Embedded platform specifications

\begin{tabular}{ll}
\hline Özellik & Açıklamas1 \\
\hline CPU & 1 GHz AM3358 ARM® Cortex- \\
RAM & A8 \\
OS & Li2 MB DDR3 \\
Kamera & Ainux Debian \\
Kamera Çözünürlüğü & Aptina MT9V024 \\
\hline
\end{tabular}

Görüntü sensörü olarak HDR (High Dynamic Range) görüntü alma özelliğine sahip bir sensör kullanılarak kameradan alınan görüntülerde oluşabilecek aşırı 1şıklık, mercek parlaması (lens flare) gibi olumsuz senaryoların sistem başarımına etkisi azaltılmıştır. Sensörden görüntü almak için gerekli sürücü dosyası (driver) Debian işletim sistemi için oluşturulmuştur. Önerilen sistem $\mathrm{C}++$ dili ile OpenCV kütüphanesi kullanılarak gerçeklenmiştir. 


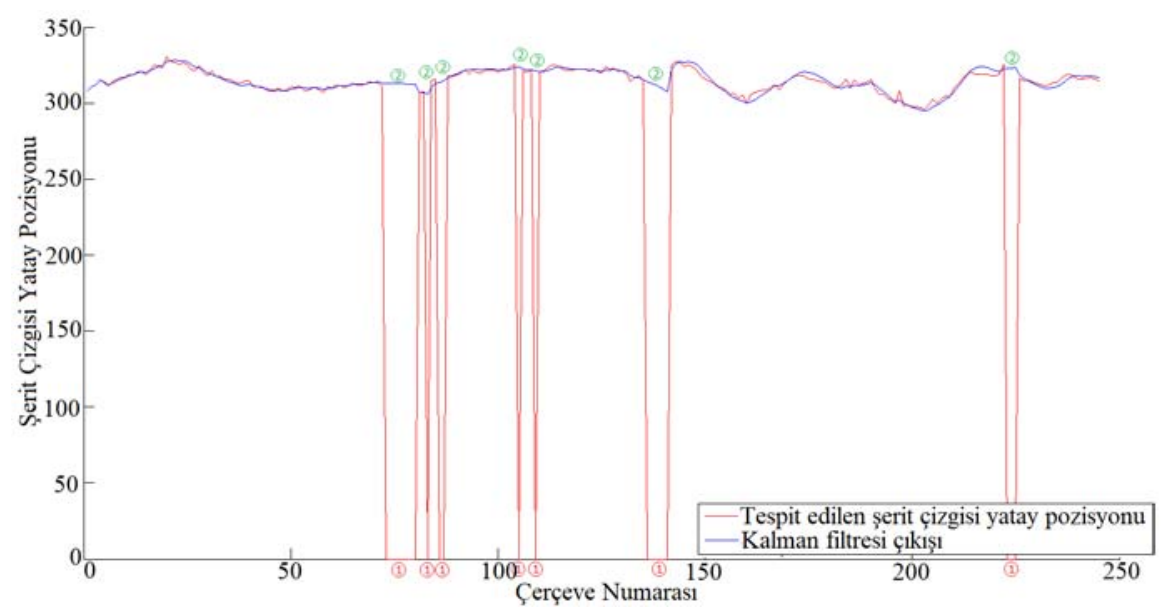

Şekil 8. Kalman filtresi ile şerit işareti konum tespiti (Lane marking position detection using Kalman filter)

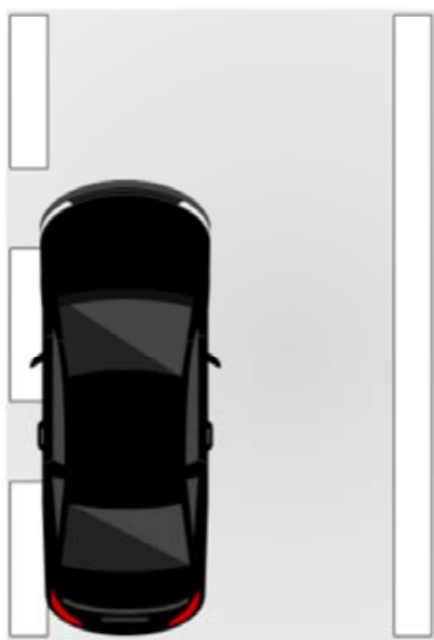

(a)

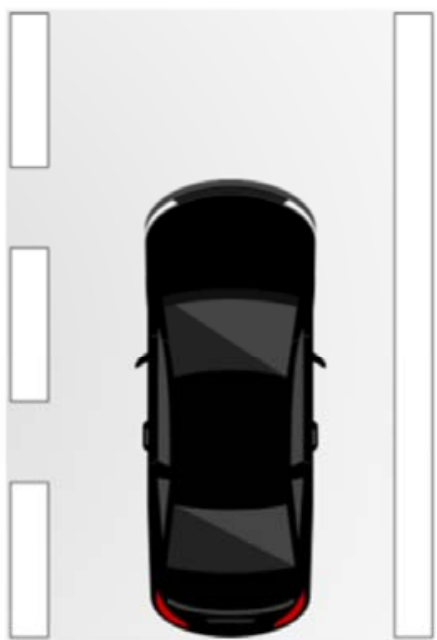

(b)
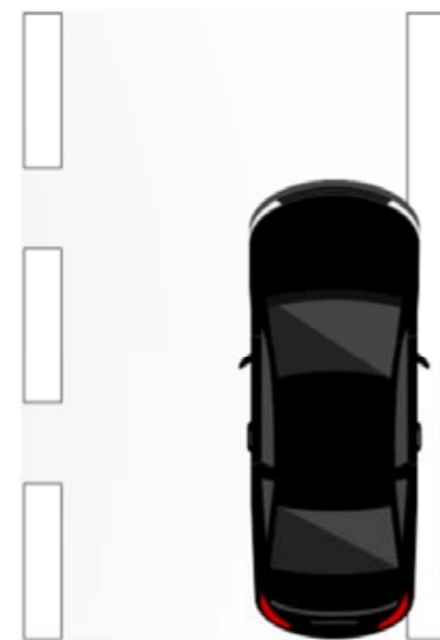

(c)

Şekil 9. Araçların şerit değişikliği durumları a) Sol şerit değişikliği b) Normal seyir c) Sağ şerit değişikliği (Lane departure states of vehicles a) Left lane departure b) Normal drive c) Right lane departure)

Gömülü platform Șekil 11'de gösterilen araçların ön camına monte edilebilecek şekilde tasarlanmış bir kasa içerisine yerleştirilmiştir. Cam montaj aparatı araçların farklı ön cam açılarına uyarlanabilecek şekilde değiştirilebilir yapıdadır. Görüntü sensörünün düşey eksendeki açısı şerit çizgilerini en iyi şekilde görüntülemek amacıyla $\pm 15^{\circ}$ derece açı aralığında elle ayarlanabilir yapıdadır.

\section{DENEYSEL SONUÇLAR (EXPERIMENTAL RESULTS)}

Şerit işareti tespit başarımını değerlendirmek için literatürde yaygın kabul görmüş genel bir yöntem bulunmamaktadır. Bazı çalışmalarda tespit başarımı öznel olarak görsel bir şekilde değerlendirilmekte, bazı çalışmalarda ise çeşitli nesnel ölçütler kullanılmaktadır. Bu çalışmada ise Eş. 5'de verilen ortalama karesel hata (Mean Square Error -MSE) ölçütü kullanılmıştır. MSE değeri tespit edilen şerit çizgisi noktas1 $\left(x_{\text {tespit }}\right)$ ile yatay eksende tespit edilen şerit çizgisi noktasına karşılık gelen yer doğrusu (ground truth) noktası $\left(x_{\text {yer doğrusu }}\right)$ arasında hesaplanmaktadır. Bu eșitlikteki $N$ MSE hesaplamasının yapılacağı nokta sayısını belirtmektedir.

$$
\text { MSE }=\frac{1}{N} \sum_{1}^{\mathrm{N}}\left(X_{\text {tespit }}-X_{\text {yer doğrusu }}\right)^{2}
$$

Bir şerit işaretinin tespit başarımını değerlendirmek için öncelikle o şerit işaretine ait yer doğrusu bilgilerinin olması gerekmektedir. Bu çalışma kapsamında sistem başarımı değerlendirmek için 4 farklı görüntü setinde toplam 1225 görüntü bulunan CalTech veri tabanı için yer doğruları el ile işaretleme yöntemiyle oluşturulmuştur. Her bir görüntü için karşılaştırma yapılacak alan üzerinde şerit işaretlerinin başlangıç, bitiş noktaları ve arada bulunan birkaç nokta daha işaretlenerek ara değerleme yöntemiyle şerit işaretlerine ilişkin yer doğruları oluşturulmuştur. Bu yer doğruları daha sonra karşılaştırma işleminde kullanılmak üzere XML (Extensible Markup Language) dosya formatında kaydedilmiştir. 


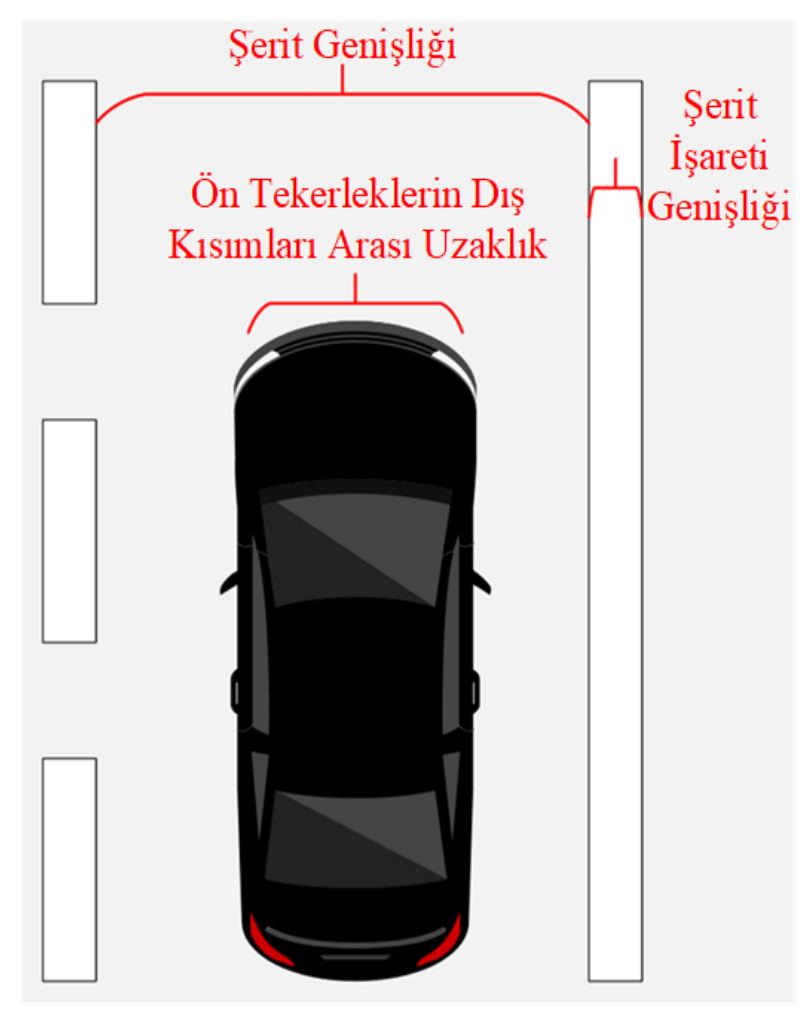

Şekil 10. Kalibrasyon parametreleri (Calibration parameters)

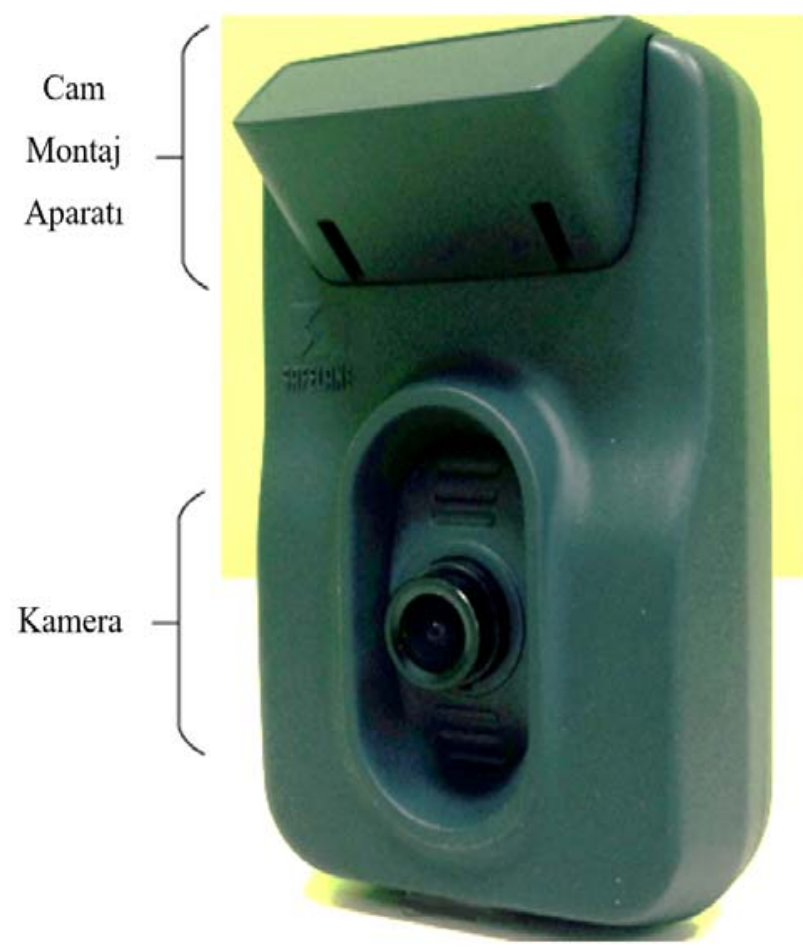

Şekil 11. Gömülü platform kasası (Case of embedded platform)

Şerit işareti tespit performansı değerlendirmesi doğruluk (accuracy - ACC) ölçütü kullanılarak gerçekleştirilmiştir. Doğruluk ölçütü Eş. 6'da verilen eşitlikteki gibi hesaplanmaktadir.

$$
A C C=\frac{T P+T N}{(T P+F N+F P+T N)}
$$

TP (True Positive) bir şerit işareti için yer doğrusu varken yöntemin başarılı bir şekilde şerit tespit etmesi, FP (False Positive) görüntü üzerinde bir şerit işareti mevcut olmadığ1 halde yöntemin şerit işareti tespit etmesi, TN (True Negative) görüntü üzerinde bir şerit işareti bulunmadığ1 durumda yönteminde şerit işareti tespit etmemesi, FN (False Negative) ise şerit işareti mevcut olduğu halde yöntemin şerit işaretini tespit edememesi durumudur.

$\mathrm{Bu}$ çalışmada bir şerit işaretinin doğru bir şekilde tespit edilmesi kararı, tespit edilen şerit işareti ile yer doğrusu arasındaki uzaklığın ortalama otoyol şerit işareti genişliğinden daha az olması durumunda verilmektedir. $\mathrm{Bu}$ bölümde verilen sonuçlarda korelasyon işlemi sırasında kullanılan Gauss fonksiyonu için veri tabanlarındaki şerit işaretleri incelenerek $\mu=0$ ve $\sigma=2$ olarak deneysel olarak belirlenmiştir. Şerit filtresi ve korelasyon işlemi için şerit işareti genişliği 15 piksel olarak seçilmiştir. Şekil 12'de önerilen yöntem ile birlikte Borkar vd. [7], Espinoza ve Torriti [11], Küçükyıldız ve Ocak [19], Gaikwad ve Lokhande [5], Mammeri vd.'nin [16] önerdiği yöntemlerin koşturulduğu CalTech veri tabanından alınan görüntüler (Cordova1 (C1), Cordova2 (C2), Washington1 (W1), Washington2 (W2)) için yer doğrusu ve görsel tespit sonuçları verilmektedir. Görüntülerde yeşil çizgiler yer doğrularını, kırmızı çizgiler ise yöntemlerin tespit sonuçlarını göstermektedir. Bu şekilden görüleceği üzere normal yol yüzeyinde karşılaştırılan bütün yöntemler şerit işaretlerini tespit edebilmektedir. Yol yüzeyinde 1ş1klılık ve gölgenin olumsuz etkisinin olduğu görüntülerde Borkar vd. [7], Küçükyıldız ve Ocak [19] ve bu çalışmada önerilen yöntem başarılı bir şekilde şerit işaretlerini tespit edebilirken diğer yöntemler yanlış tespitler yapabilmektedir.

Tablo 3'te önerilen yöntem ile Borkar vd. [7], Espinoza ve Torriti [11], Küçükyıldız ve Ocak [19], Gaikwad ve Lokhande [5], Mammeri vd.'nin [16] önerdiği yöntemlerin CalTech veri tabanı üzerinde nicel (quantitative) performans değerlendirmeleri gösterilmektedir. Tablo 3 sol şerit işareti tespit, sağ şerit işareti tespit, sol ve sağ şerit işareti tespit ortalaması ve dizilerde bulunan görüntü sayılarıyla orantılanarak elde edilen ortalama tespit değerlerini içermektedir. Kameradan alınan görüntülerde 1 ş1kl1lık etkisinin yoğun olarak gözlendiği cordova2 görüntü setinde ve gölge etkisinin yoğun olduğu washington1 görüntü setinde özellikle Mammeri vd.'nin [16] önerdiği yöntemin şerit işareti tespit performansı düşüktür. Gaikwad ve Lokhande'nin [5] ön işlem adımında bulunan filtrenin uyarlanabilir olmamasının tespit performansı üzerindeki olumsuz etkisi farklı 1şıklılık durumlarına sahip corvada2 görüntü seti için tablodan gözlenmektedir. Küçükyıldız ve Ocak'ın [19] önerdiği yöntemin görüntü üzerinde tespit edilen Hough çizgilerini eleme kriterleri genel olarak görüntü setlerinde başarılı sonuçlar vermektedir. Ancak bu yöntem temel olarak yüksek Hough skoru üzerinden 

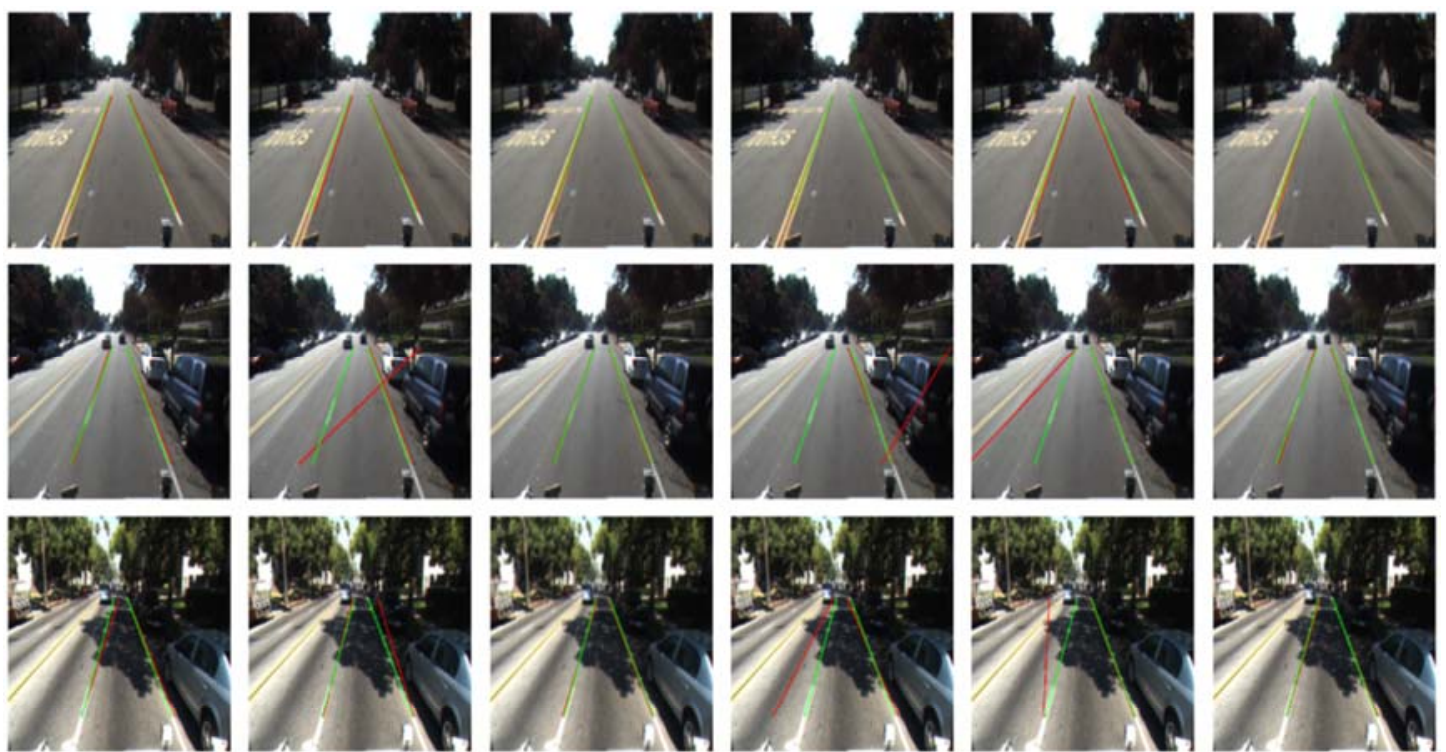

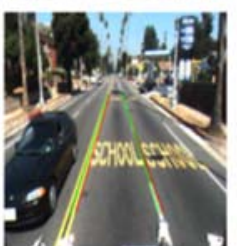

(a)

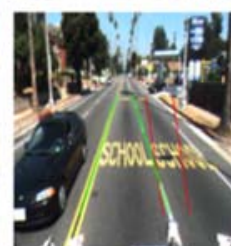

(b)

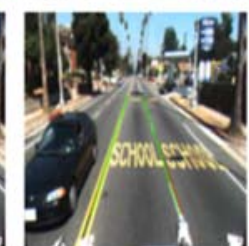

(c)

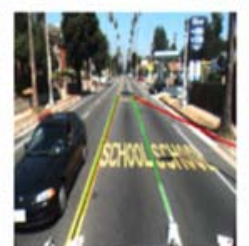

(d)

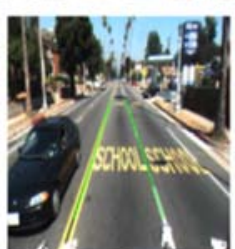

(e)

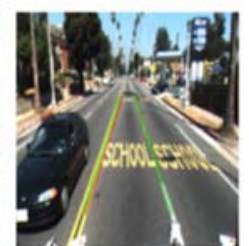

(f)

Şekil 12. Görsel şerit işareti tespit sonuçları a) Borkar vd. b) Espinoza ve Torriti c) Küçükyıldız ve Ocak d) Gaikwad ve Lokhande e) Mammeri vd. f) Önerilen yöntem (Visual results of lane marking detection methods a) Borkar et al. b) Espinoza and Torriti c) Küçükyıldız ve Ocak d) Gaikwad and Lokhande e) Mammeri et al. f) Proposed Method)

Tablo 3. Şerit işareti tespit yöntemlerinin performans değerlendirilmesi (Performance evaluation of lane marking detection methods)

\begin{tabular}{llllll}
\hline Borkar vd. [7] & $\begin{array}{l}\text { Espinoza ve } \\
\text { Torriti [11] }\end{array}$ & $\begin{array}{l}\text { Küçükyıldız ve } \\
\text { Ocak [19] }\end{array}$ & $\begin{array}{l}\text { Gaikwad ve } \\
\text { Lokhande [5] } \\
(2012)\end{array}$ & $\begin{array}{l}\text { Mammeri vd. } \\
\text { [16] (2016) }\end{array}$ & $\begin{array}{l}\text { Önerilen } \\
\text { Yöntem }\end{array}$ \\
\hline
\end{tabular}

Sahne Sol Să̆ Ort. Sol Sağ Ort. Sol Sağ Ort. Sol Sağ Ort. Sol Sağ Ort. Sol Sağ Ort.

C1 $\quad \begin{array}{llllllllllllllllll}0,77 & 0,68 & 0,72 & 0,63 & 0,66 & 0,64 & 0,83 & 0,91 & 0,87 & 0,68 & 0,36 & 0,52 & 0,88 & 0,70 & 0,79 & 0,91 & 0,93 & 0,92\end{array}$

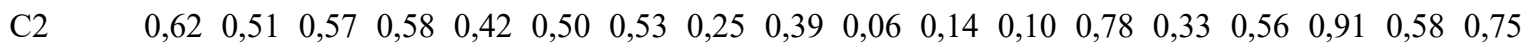

$\begin{array}{lllllllllllllllllll}\mathrm{W} 1 & 0,49 & 0,67 & 0,58 & 0,62 & 0,36 & 0,49 & 0,76 & 0,79 & 0,78 & 0,67 & 0,11 & 0,39 & 0,27 & 0,26 & 0,27 & 0,76 & 0,70 & 0,73\end{array}$

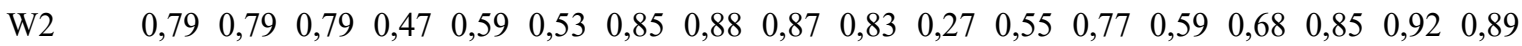

$\begin{array}{llllllllllllllllllllll}\text { Ort. } & 0,65 & 0,64 & 0,64 & 0,58 & 0,49 & 0,53 & 0,71 & 0,65 & 0,68 & 0,50 & 0,20 & 0,35 & 0,66 & 0,44 & 0,55 & 0,86 & 0,78 & 0,82\end{array}$

tespitlerini gerçekleştirdiği için özelikle kaldırım ve benzeri yol üzerinde bulunan yapılardan etkilenerek yanlış tespitler gerçekleştirebilmektedir. Ayrıca Sobel filtresi çıkışında şerit çizgileri benzeri yüksek kenar bilgileri oluşturan yapılarda sistem performansını olumsuz etkilemektedir. Bu çalışmada önerilen yöntem ise yol yüzeyi üzerinde bilgilendirme yazılarının bulunduğu washington2 görüntü setinde yüksek tespit performansıyla öne çıkmaktadır. Tablo 3 genel olarak incelendiğinde ise bu çalışmada önerilen sistemin şerit işareti tespitinde karşılaştırılan yöntemlere göre daha başarılı sonuçlar verdiği görülmektedir. Bu çalışmada önerilen şerit işareti tespit yönteminin şerit filtresi ve korelasyon işlemi adımlarında şerit işareti genişliği bir parametre olarak kullanılmaktadır. 


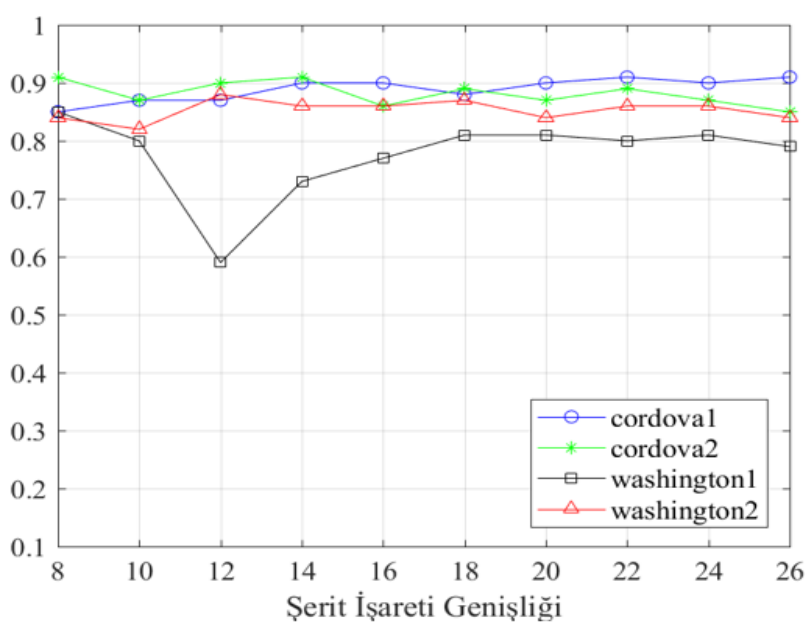

(a)

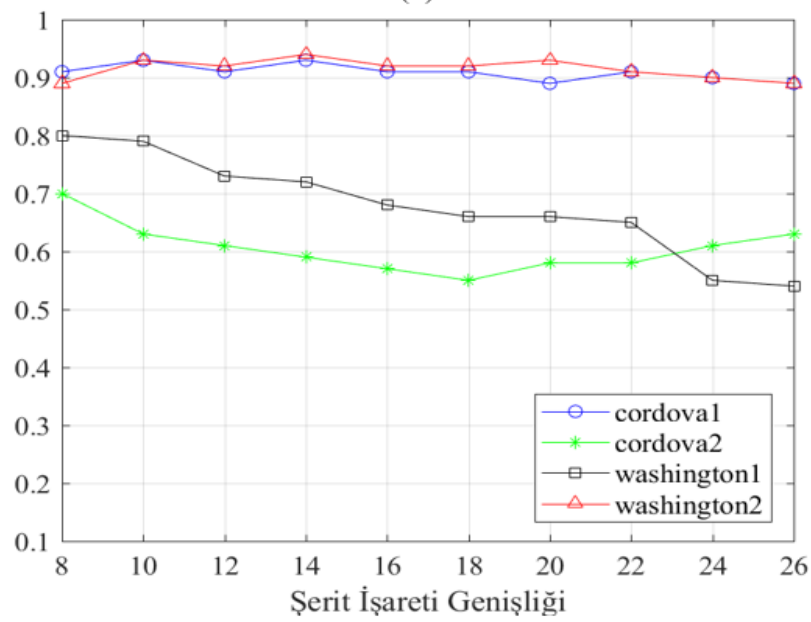

(b)

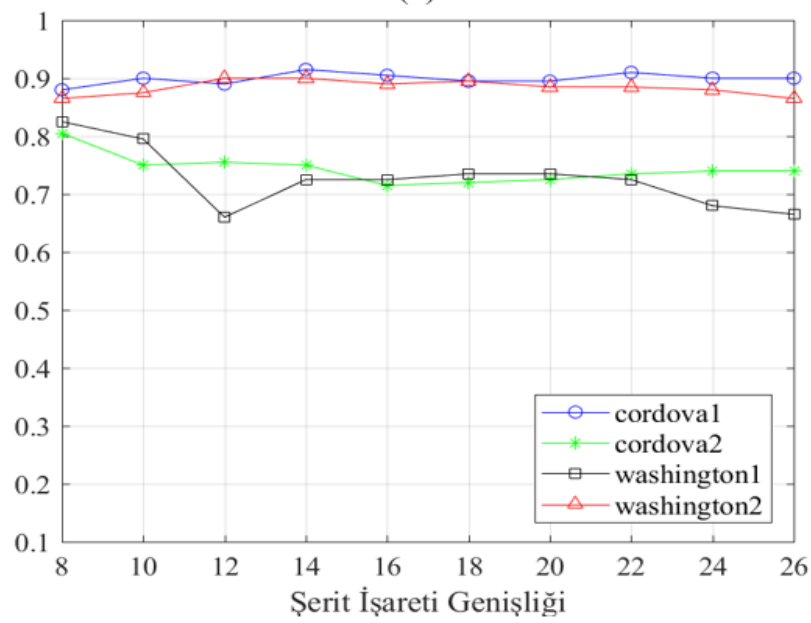

(c)

Şekil 13. Şerit işareti genişliği temelli şerit işareti tespit performansı değerlendirilmesi a) Sol şerit işareti tespit performansı b) Sağ şerit işareti tespit performansı c) Ortalama şerit işareti tespit performansı

(Evaluation of lane marking width based lane marking detection performance a) Left lane marking detection performance b) Right lane marking detection performance c) Average lane marking detection performance)
Önerilen şerit işareti tespit yönteminin performansı şerit işareti genişliği parametresinin farklı değerlerinde incelenmiştir. Şekil 13'de yatay eksen incelenen şerit genişliği değerlerini, dikey eksen ise önerilen sisteminin bu değerlere göre tespit başarımını (doğruluk) göstermektedir. Şekil 13(a)'da sol şerit işareti tespit başarımı, Şekil 13(b)'de sağ şerit işareti tespit başarımı ve Şekil 13(c)'de ise sol ve să şerit işareti tespit başarımlarının ortalaması gösterilmektedir.

Şekil 13(a), Şekil 13(b) ve Şekil 13(c) incelendiğinde sistem performansının parametre seçimine bağlı olarak önemli ölçüde değişmediği görülmektedir. Sonuç olarak, bu durum önerilen şerit tespit yönteminin sadece belirli bir kamera düzeneği, veri tabanı ve parametreler için özelleşmiş bir sistem olmadığı açıktır. Tablo 4'te Tablo 3'te performans karşılaştırması verilen yöntemlerin ortalama çalışma süreleri verilmektedir. Bu çalışma süreleri önerilen yöntem ve diğer yöntemlerin benzer optimizasyon seviyesinde MATLAB' da kodlanarak 2.3 GHz Quad core işlemciye ve 16GB RAM'e sahip bir bilgisayar üzerinde koşturulması ile elde edilmiştir. Tablo 4'te verilen çalışma süreleri dikkate alındığında, önerilen yöntem hem yüksek performansı hem de düşük hesapsal yükü ile diğer yöntemlere göre şerit tespitinde öne çıkarmaktadır.

$\mathrm{Bu}$ çalışma kapsamında gerçekleştirilen şeritten ayrılma uyarı sisteminin gömülü platform uygulaması, kameradan alınan $752 \times 480$ (WVGA) çözünürlüğe sahip giriş görüntüleri için 16 fps işlem hızıyla gerçek zamanlı olarak çalışmaktadır. Tablo 5'te geliştirilen gömülü platform uygulamasının ara işlem basamaklarının bir görüntü çerçevesi için harcadığ 1 süreleri verilmektedir. Küçükyıldız ve Ocak'ın [19] önerdiği yöntem ise $720 \times 486$ (NTSC) çözünürlüğe sahip giriş görüntüleri için bir DSP üzerinde 30 fps işlem hızıyla çalışmaktadır. Gömülü sistemlere uyarlanan iki yöntem karşılaştırıldığında bu çalışma kapsamında önerilen sistemin şerit işareti tespit performansıyla öne çıktığı görülmektedir. Ancak bu aşamada [19]' da önerilen sistemde kullanılan DSP'nin işaret işlemeye özgü bir işlem birimi olduğu, bu çalışmada kullanılan işlemcinin ise ARM tabanlı genel amaçlı bir işlemci olduğu gözden kaçırılmamalıdır. Şekil 14'de gömülü platform uygulamasının bir otomobilin ön camına montajı yapılarak sistemden alınan görüntüler üzerinden görsel şerit tespit sonuçları verilmektedir. Bu şekilde kırmızı renkli çizgiler şerit işareti tespit sonuçlarını, yeşil çizgiler ise şeritten ayrılma uyarı tespiti için kullanılan ortalama çizgiyi göstermektedir.

\section{SONUÇLAR (CONCLUSIONS)}

$\mathrm{Bu}$ çalışma kapsamında ileri sürücü destek sistemlerinde kullanılabilecek gömülü bir şeritten ayrılma sistemi geliştirilmiştir. Geliştirilen sistemde ham görüntüler sensör aracılığı ile alındıktan sonra sabit bir ilgi alanı seçilerek işlemler bu ilgi alanı üzerinde yapılmakta ve böylelikle gerçek zamanlı çalışma açısından önemli bir avantaj sağlanmaktadır. Gömülü sistem üzerinde koşan algoritma bu 
Tablo 4. Şerit işareti tespit yöntemlerinin PC üzerinde bir çerçeve için ortalama çalışma süreleri (The average running times of the lane marking detection methods on a PC for a single input frame)

\begin{tabular}{lllllll}
\hline & $\begin{array}{l}\text { Borkar vd. } \\
{[7](2012)}\end{array}$ & $\begin{array}{l}\text { Espinoza ve } \\
\text { Torriti } \\
{[11](2013)}\end{array}$ & $\begin{array}{l}\text { Küçükyılddz ve } \\
\text { Ocak [19] (2014) })\end{array}$ & $\begin{array}{l}\text { Gaikwad ve } \\
\text { Lokhande } \\
{[5](2015)}\end{array}$ & $\begin{array}{l}\text { Mammeri vd. } \\
{[16](2016)}\end{array}$ & $\begin{array}{l}\text { Önerilen } \\
\text { Yöntem }\end{array}$ \\
\hline Sahne & $8520 \mathrm{~ms}$ & $2520 \mathrm{~ms}$ & $169 \mathrm{~ms}$ & $180 \mathrm{~ms}$ & $50 \mathrm{~ms}$ & $306 \mathrm{~ms}$ \\
\hline
\end{tabular}

Tablo 5. Gömülü platform üzerinde 1 görüntü çerçevesi için işlem süreleri (Processing times for an image frame on the embedded platform)

\begin{tabular}{ll}
\hline İşlem & Süre (ms) \\
\hline Görüntüye kamera sürücüsü üzerinden erişim & 0,00254 \\
Kırpma & 0,02950 \\
Bayer desenden RGB renk uzayına dönüştürme & 27,38946 \\
Gri seviyeli görüntüye dönüştürme & 6,59804 \\
Şerit işareti filtresi & 1,21850 \\
Eşikleme & 0,85300 \\
Gauss korelasyonu & 22,11380 \\
RANSAC işlemi & 1,08179 \\
Kalman filtresi & 0,25933 \\
Toplam & 59,54590 \\
\hline
\end{tabular}
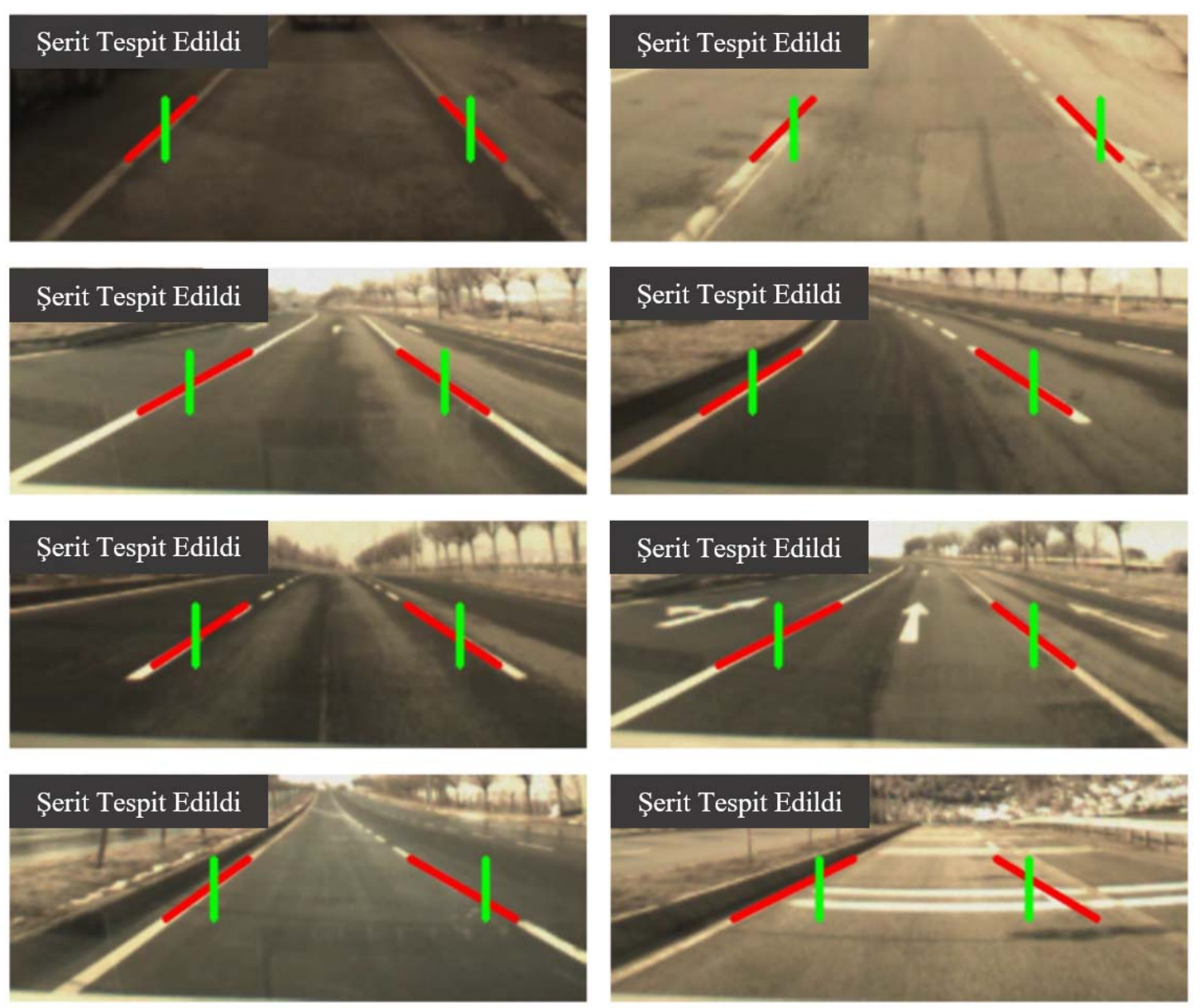

Şekil 14. Gömülü platform uygulaması görsel şerit işareti tespit sonuçları (Visual results of lane marking detection on embedded platform)

iş için özelleşmiş ve gerçek zamanlı çalışmaya uygun olacak şekilde tasarlanmıştır. Sonuç olarak geliştirilen sistemin 1 $\mathrm{GHz}$ frekansındaki ARM Cortex-A8 işlemci üzerinde
$752 \times 480$ piksel çözünürlüğe sahip giriş görüntüleri için 16 fps'de gerçek zamanlı olarak çalışması sağlanmıştır. Görüntü alma aşamasında farklı RGB görüntü oluşturma 
aşaması önemli miktarda zaman harcamakta olup ileriki çalışmalarda bu sürenin azaltılması hedeflenmektedir. Önerilen haliyle bu çalışmada geliştirilen sistem gerçek zamanlı çalışmasının yanı sıra ortalama \%82 şerit tespit performansıyla yakın zamanda literatürde önerilen benzer sistemlere göre daha yüksek bir şerit tespit başarımına sahiptir.

\section{TEŞEKKÜR (ACKNOWLEDGEMENT)}

$\mathrm{Bu}$ çalışma 7140156 nolu TÜBİTAK-TEYDEB projesi kapsamında desteklenmiştir. Yazarlar M. Torres-Torriti'ye yöntemlerinin uygulamasını paylaştığ 1 için, H. Ocak ve A. Borkar'a yöntemlerini uygulamada yardımlarından dolayı, hakemlere ise çalışmanın sunumunu iyileştirilmesini sağlayan geribildirimleri için teşekkür eder.

\section{KAYNAKLAR (REFERENCES)}

1. COWI, Cost-benefit assessment and prioritization of vehicle safety technologies (TREN-ECON2-002), Avrupa Komisyonu Enerji ve Taşımacılık Genel Müdürlüğü, Brüksel-Belçika, 2006.

2. Kaya H., Çavuşoğlu A., Çakmak H., Şen B., Delen D., Supporting the diagnosis process and processes after treatment by using image segmentation and image simulation techniques: Keratoconus example, Journal of the Faculty of Engineering and Architecture of Gazi University, 31 (3), 737-747, 2016.

3. Avc1 E., Tuncer T., Avc1 D., A new data hiding algorithm based on minesweeper game for binary images, Journal of the Faculty of Engineering and Architecture of Gazi University, 3(4), 951-959, 2016.

4. Selvi E., Selver M., Kavur A., Güzeliş C., Dicle O., Segmentation of abdominal organs from MR images using multi-level hierarchical classification, Journal of the Faculty of Engineering and Architecture of Gazi University, 30 (3), 533-546, 2015.

5. Gaikwad V., Lokhande S., Lane departure identification for advanced driver assistance, IEEE Transactions on Intelligent Transportation Systems, 16 (2), 910-918, 2015.

6. Duda R.O., Hart P.E., Use of the Hough transformation to detect lines and curves in pictures, Communications of the ACM, 15 (1), 11-15, 1972.

7. Borkar A., Hayes M., Smith, M.T., A novel lane detection system with efficient ground truth generation, IEEE Transactions on Intelligent Transportation Systems, 13 (1), 365-374, 2012.

8. Bertozzi M., Broggi A., GOLD: A parallel real-time stereo vision system for generic obstacle and lane detection, IEEE Transactions on Image Processing, 7 (1), 62-81, 1998.

9. Fischler M.A., Bolles R.C., Random sample consensus: a paradigm for model fitting with applications to image analysis and automated cartography, Communications of the ACM, 24 (6), 381-395, 1981.

10. Kalman R.E., A new approach to linear filtering and prediction problems. Journal of Basic Engineering, 82 (1), 35-45, 1960.

11. Tapia-Espinoza R., Torres-Torriti M., Robust lane sensing and departure warning under shadows and occlusions, Sensors, 3 (1), 3270-3298, 2013.

12. Torr P.H.S., Zisserman A., MLESAC: A new robust estimator with application to estimating image geometry, Computer and Vision Image Understanding, 78 (1), 138-156, 2000.

13. Yoo H., Yang U., Sohn K., Gradient-enhancing conversion for illumination-robust lane detection, IEEE Transactions on Intelligent Transportation Systems, 14 (3), 1083-1094, 2013.

14. You F., Zhang R., Zhong L., Wang H., Xu J., Lane detection algorithm for night-time digital image based on distribution feature of boundary pixels, Journal of the Optical Society of Korea, 17 (2), 188-199, 2013.

15. Otsu N., A threshold selection method from gray-level histograms, IEEE Transactions on Systems, Man and Cybernetics, 9 (1), 62-66, 1979.

16. Mammeri A., Boukerche A., Tang Z., A real-time lane marking localization, tracking and communication system, Computer Communications, 73, 132-143, 2016.

17. Matas J., Chum O., Urban M., Pajdla T., Robust wide baseline stereo from maximally stable extremal regions, Image and Vision Computing, 22 (10), 761-767, 2004.

18. Stephens R.S., Probabilistic approach to the Hough transform, Image and Vision Computing, 9 (1), 66-71, 1991.

19. Küçükyıldız G., Ocak H., Development and optimization of a DSP-based real-time lane detection algorithm on a mobile platform, Turkish Journal of Electrical Engineering and Computer Sciences, 22 (6), 1484-1500, 2012.

20. Shin B., Tao J., Klette R., A superparticle filter for lane detection, Pattern Recognition, 48 (11), 3333-3345, 2015.

21. Nieto M., Laborda J.A., Salgado L., Road environment modeling using robust perspective analysis and recursive Bayesian segmentation, Machine Vision and Applications, 22 (6), 927-945, 2011.

22. Aly M., Real time detection of lane markers in urban streets, IEEE Intelligent Vehicle Symposium, Hollanda, 7-12, 2008.

23. Funk N., A study of the Kalman filter applied to visual tracking, Teknik Rapor, University of Alberta, 2003.

24. Bar-Shalom Y., Birmiwal K., Variable dimension filter for maneuvering target tracking, IEEE Transactions on Aerospace and Electronic Systems, 18 (5), 621-629, 1982. 